\title{
Metabolic Disorder in Chronic Obstructive Pulmonary Disease (COPD) Patients: Towards a Personalized Approach Using Marine Drug Derivatives
}

\author{
Palma Lamonaca ${ }^{1}$, Giulia Prinzi ${ }^{1}$, Aliaksei Kisialiou ${ }^{1}$, Vittorio Cardaci ${ }^{2}$, Massimo Fini ${ }^{3}$ and \\ Patrizia Russo ${ }^{1, *}$ \\ 1 Clinical and Molecular Epidemiology, IRCSS San Raffaele Pisana, Via di Valcannuta 247, I-00166 Rome, Italy; \\ palma.lamonica@sanraffaele.it (P.L.); giulia.prinzi@sanraffaele.it (G.P.); alesseus@gmail.com (A.K.) \\ 2 Department of Pulmonary Rehabilitation, IRCCS San Raffaele Pisana, Via della Pisana 235, \\ I-00163 Rome, Italy; vittorio.cardaci@sanraffaele.it \\ 3 Scientific Direction, IRCSS San Raffaele Pisana, Via di Valcannuta 247, I-00166 Rome, Italy; \\ massimo.fini@sanraffaele.it \\ * Correspondence: patrizia_russo@hotmail or itorpatrizia.russo@sanraffaele.it; Tel.: +39-06-5225663
}

Academic Editor: Peer B. Jacobson

Received: 22 November 2016; Accepted: 15 March 2017; Published: 20 March 2017

\begin{abstract}
Metabolic disorder has been frequently observed in chronic obstructive pulmonary disease (COPD) patients. However, the exact correlation between obesity, which is a complex metabolic disorder, and COPD remains controversial. The current study summarizes a variety of drugs from marine sources that have anti-obesity effects and proposed potential mechanisms by which lung function can be modulated with the anti-obesity activity. Considering the similar mechanism, such as inflammation, shared between obesity and COPD, the study suggests that marine derivatives that act on the adipose tissues to reduce inflammation may provide beneficial therapeutic effects in COPD subjects with high body mass index (BMI).
\end{abstract}

Keywords: chronic obstructive pulmonary disease; comorbidities; management strategy; marine compound; metabolic disorder; inflammation; systems approaches

\section{Introduction}

Chronic Obstructive Pulmonary Disease (COPD) is a complex illness whose development depends on the interaction between environmental and genetic risk factors. COPD is characterized by enduring airflow constraint, often resistant to bronchodilators and corticosteroids [1-4]. Although, COPD is considered "part of a worldwide tobacco-related disease epidemic", at least one fourth of patients are non-smokers [4]. Thus, other environmental factors such as indoor/air pollution, second-hand smoke (during pregnancy, early childhood, or life), chemical fumes or dust as well as genetic factors may contribute to its development [1-4]. Several regions of the genome may be associated with COPD. Genetic variants in the alpha- 1 antitrypsin (AAT, autosomal recessive) gene, discovered in the early 1960s, are associated with a major risk to develop COPD. The onset of COPD is between 40 and 50 years in smoker carriers Alpha-1 Antitrypsin Deficiency (AATD), whereas, in non-smokers, the onset is delayed to 60 years [5]. However, these variants account for only $1 \%-2 \%$ of all COPD cases [5]. Genetic variations in the cluster on chromosome 15, encoding the nicotinic acetylcholine receptor subunits (CHRNA5-CHRNA3-CHRNB4), are correlated with tobacco addiction and increased risk of COPD, peripheral artery disease, lung cancer and obesity [6-8]. Different studies on lung tissue and peripheral blood identified increased expression of genes related to inflammatory pathways and 
immune regulation [9]. More studies are warranted to recognize those genes and pathways occurring in COPD. Pathological signs such as remodeling and straitening of the small airways anddestruction of the lung parenchyma are consequential to the chronic inflammation. Chronic inflammation contributes to the extra pulmonary effects, the so-called "systemic effects", of COPD and regulates disease expression, burden, and mortality $[10,11]$. COPD patients commonly show several progressive failures connected to the "cardiopulmonary-metabolic axis" (CMA). The CMA provides oxygen and nutrients to the body. A link between metabolic syndrome (MetS code E88.81), or better to metabolic disorder (MetD), and lung diseases has been reported by several cross-sectional and longitudinal studies (as reviewed, recently, by Baffi et al. [12]). The concept of MetS evolved over time to MetD; indeed, MetD is a complex disorder thought as a cluster of conditions sustaining a "disorder in energy use and storage" characterized by central obesity, dyslipidemia, high blood sugar levels (hyperglycemia), hypertriglyceridemia, and low high-density lipoprotein cholesterol levels. MetD is also associated with a prothrombotic and a pro-inflammatory state [13]. A recent systematic review, that includes 19 studies involving 4208 COPD patients, evidences the presence of MetD in the 34\% of population with high prevalence of arterial hypertension, abdominal obesity, and hyperglycemia [14]. In a group of elderly 877 patients (74 years median) admitted to San Raffaele Group Pulmonary Rehabilitation Units, $84 \%$ patients have $1-4$ comorbidities and $10 \%>4$ with an increasing trend of multimorbidity over recent years, mainly 58.6\% (514 patients) suffer from arterial hypertension, $24.4 \%$ (214 patients) diabetes, $21.4 \%$ (188 patients) obesity and 7\% (61 patients) dyslipidemia [15]. It has been reported that one or more components of the MetD are present in each patients that are in part steroids treatment and/or physical inactivity independent [13]. Actually, although the impacts of MetD, as well as other comorbidities, in the management of COPD is well acknowledged, no certainty exists on treatment of MetD to reduce its effects on the respiratory system. The uncertainty is linked to the complex interplay among genes, epigenetic, lifestyle and environmental exposures that lead to different COPD phenotypes (i.e., obesity/dyslipidemia/insulin-resistance or underweight/osteoporosis/muscle wasting, see Figure 1).

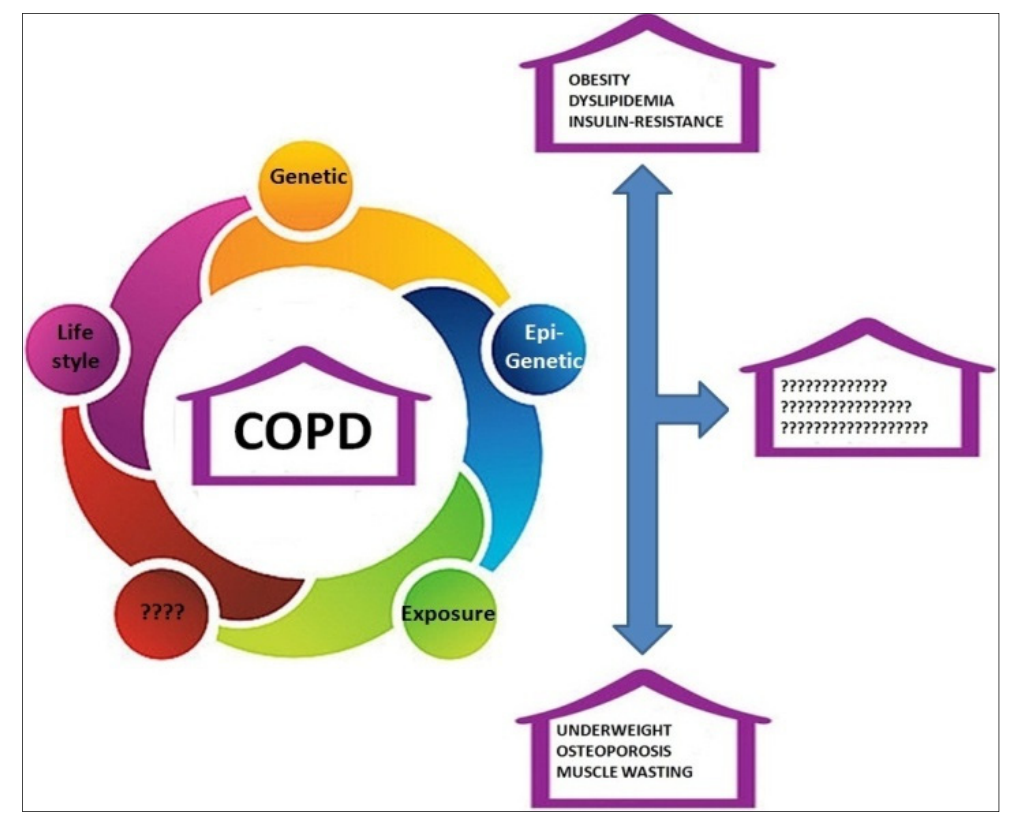

Figure 1. Constellations of different Metabolic Disorders and theoretical underlying "types" in COPD. Distinct pathophysiological mechanisms (genetic, epigenetic, environmental factors, life style) might underlie the occurrence of groups of Metabolic Disorders in patients with COPD. 
The sub-optimal phenotyping of COPD patients partially explains the nonoccurrence of therapeutic COPD breakthroughs. Treatment may be thoughtfully palliative and moreover different patients respond in different ways to treatment. Commonly, the presence of MetD does not change the treatment of COPD that is treated independently of it [16].

Natural products, obtained from living organisms, such as most plants, microbes, and animals are an incomparable source of molecular diversity in drug discovery and have been generated new drugs (secondary metabolites) or drug derivatives [17,18]. Starting from 1969, U.S. Food and Drug Administration (FDA)/European Medicines Agency (EMA) approved eight drugs obtained from marine sources (Figure 2 and Table 1).

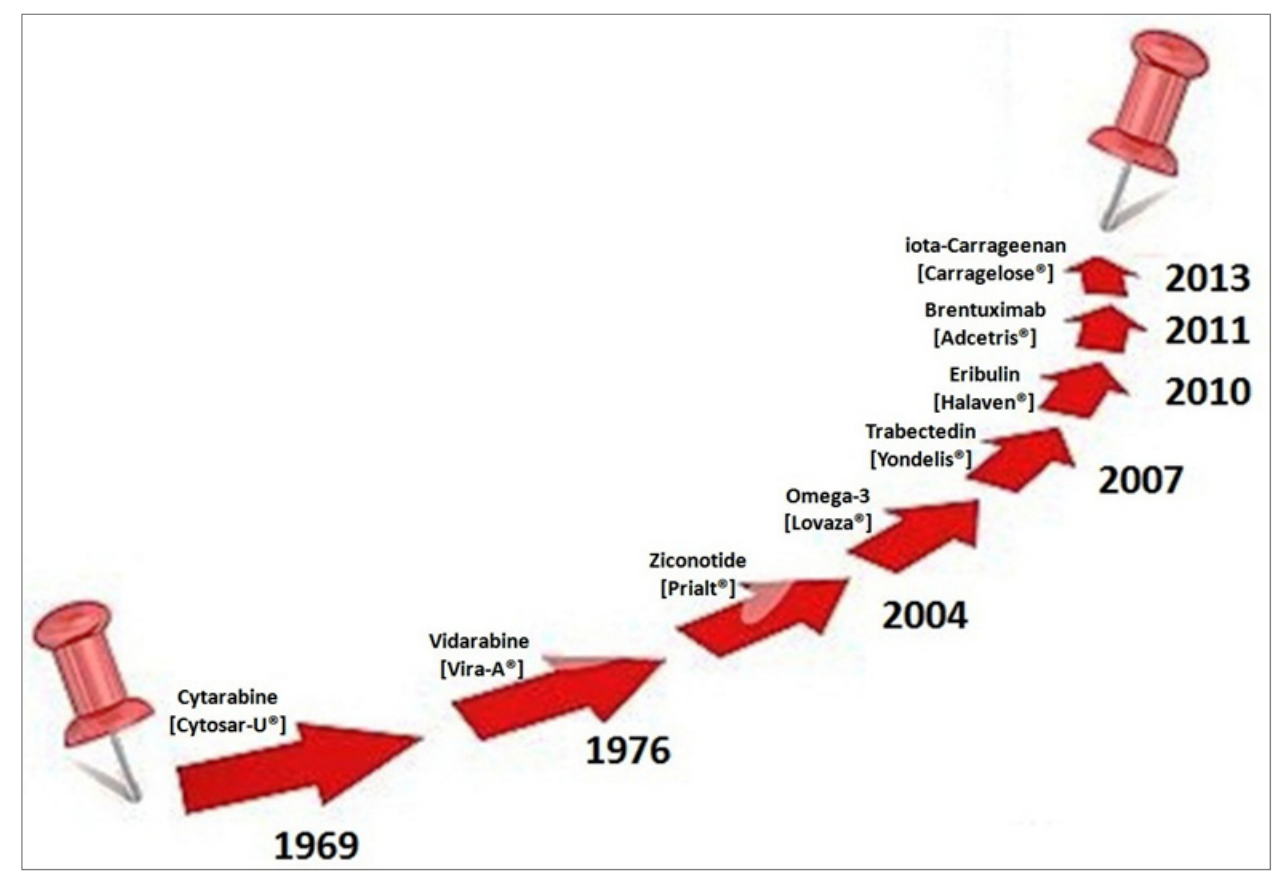

Figure 2. Marine drugs approved by FDA (U.S. Food and Drug Administration)/EMA (European Medicines Agency) from 1969 to 2013.

Table 1. FDA/EMA drugs approved obtained by marine sources.

\begin{tabular}{|c|c|c|}
\hline Drug & Systematic (IUPAC) Name & Indication/Mechanism \\
\hline $\begin{array}{l}\text { Cytarabine [Cytosar-U }{ }^{\circledR} \text { ] ATC } \\
\text { code: L01BC01 Source: } \\
\text { Cryptothecacrypta Phylum: } \\
\text { Bryophyta Class:Bryopsida }\end{array}$ & $\begin{array}{l}\text { 4-amino-1-[(2R,3S,4R,5R)-3, } \\
\text { 4-dihydroxy-5- } \\
\text { (hydroxymethyl)oxolan-2-yl] } \\
\text { pyrimidin-2-one }\left[\mathrm{C}_{9} \mathrm{H}_{13} \mathrm{~N}_{3} \mathrm{O}_{5}\right]\end{array}$ & $\begin{array}{l}\text { Anticancer DNA } \\
\text { synthesis interference }\end{array}$ \\
\hline $\begin{array}{l}\text { Eribulin [Halaven }{ }^{\circledR} \text { ] ATC code: } \\
\text { L01XX41 Synthetic macrocyclic } \\
\text { analogue of halichondrin B Source: } \\
\text { Halichondria okadai Phylum: } \\
\text { Porifera Class: Demospongiae }\end{array}$ & $\begin{array}{l}\text { 2-(3-Amino-2-hydroxypropyl) } \\
\text { hexacosahydro-3-methoxy-26- } \\
\text { methyl-20,27-bis(methylene)11,15-18, } \\
\text { 21-24,28-triepoxy-7,9-ethano-12, } \\
\text { 15-methano-9H,15H-furo(3,2-i)furo }\left(2^{\prime}, 3^{\prime}-5,6\right) \\
\text { pyrano(4,3-b)(1,4)dioxacyclopentacosin-5-(4H)- } \\
\text { one }\left[\mathrm{C}_{40} \mathrm{H}_{59} \mathrm{NO}_{11}\right]\end{array}$ & $\begin{array}{l}\text { Anticancer Microtubule } \\
\text { dynamics inhibitor }\end{array}$ \\
\hline
\end{tabular}


Table 1. Cont.

\begin{tabular}{|c|c|c|}
\hline Drug & Systematic (IUPAC) Name & Indication/Mechanism \\
\hline $\begin{array}{l}\text { Trabectedin [Yondelis }{ }^{\circledR} \text { ] ATC } \\
\text { code: L01CX01 Source: } \\
\text { Ecteinascidia turbinate Phylum: } \\
\text { Chordata Class: Ascidiacea }\end{array}$ & $\begin{array}{l}\left(1^{\prime} R, 6 R, 6 a R, 7 R, 13 S, 14 S, 16 R\right)- \\
6^{\prime}, 8,14 \text {-trihydroxy- } 7^{\prime}, 9- \\
\text { dimethoxy-4,10,23-trimethyl- } \\
\text { 19-oxo-3', } 4^{\prime}, 6,7,12,13,14,16- \\
\text { octahydrospiro[6,16-(epithiopropano- } \\
\text { oxymethano)-7,13-imino-6aH-1,3- } \\
\text { dioxolo[7,8]isoquino[3,2-b][3]benzazocine- } \\
20,1^{\prime}\left(2^{\prime} H\right) \text {-isoquinolin]-5-yl acetate } \\
{\left[\mathrm{C}_{39} \mathrm{H}_{43} \mathrm{~N}_{3} \mathrm{O}_{11} \mathrm{~S}\right]}\end{array}$ & $\begin{array}{l}\text { Anticancer DNA binding and } \\
\text { alkylation at the N2 position of G } \\
\text { causing DNA bending toward the } \\
\text { major groove. Interfering } \\
\text { activated transcription, } \\
\text { transcription-coupled nucleotide } \\
\text { excision repair (TCR) complex } \\
\text { poisoning, RNA polymerase } \\
\text { degradation, DNA double-strand } \\
\text { breaks generation }\end{array}$ \\
\hline $\begin{array}{l}\text { Brentuximab [Adcetris }{ }^{\circledR} \text { ] ATC } \\
\text { code: L01XC12 synthetic } \\
\text { dolastatin } 10 \text { Source: Dolabella } \\
\text { auricularia Phylum: Mollusca Class: } \\
\text { Gastropoda }\end{array}$ & $\begin{array}{l}\text { Antibody-monomethyl auristatin } \\
\text { Econjugate }\left[\mathrm{C}_{6476} \mathrm{H}_{9930} \mathrm{~N}_{1690} \mathrm{O}_{2030} \mathrm{~S}_{40}\right. \\
\left.\left(\mathrm{C}_{68} \mathrm{H}_{105} \mathrm{~N}_{11} \mathrm{O}_{15}\right) 3-5\right]\end{array}$ & $\begin{array}{l}\text { Anticancer Tubulin } \\
\text { polymerizationblock }\end{array}$ \\
\hline $\begin{array}{l}\text { Ziconotide [Prialt }{ }^{\circledR} \text { ] ATC code: } \\
\text { N02BG08 Source: Conus magus. } \\
\text { Phylum: Mollusca Class: } \\
\text { Gastropoda }\end{array}$ & $\begin{array}{l}\text { Peptide: H-Cys-Lys-Gly-Lys- Gly-Ala- } \\
\text { Lys-Cys-Ser-Arg-Leu-Met-Tyr-Asp- } \\
\text { Cys-Cys-Thr-Gly-Ser-Cys-Arg-Ser- } \\
\text { Gly-Lys-Cys- } \mathrm{NH}_{2}\left[\mathrm{C}_{102} \mathrm{H}_{172} \mathrm{~N}_{36} \mathrm{O}_{32} \mathrm{~S}_{7}\right]\end{array}$ & $\begin{array}{l}\text { Anti-pain Selective N-type } \\
\text { voltage-gated calcium } \\
\text { channel blocker }\end{array}$ \\
\hline $\begin{array}{l}\text { Vidarabine [Vira-A }{ }^{\circledR} \text { ] ATC code: } \\
\text { J05AB03 Source: Tectitethya crypta } \\
\text { Phylum: Porifera Class: } \\
\text { Demospongiae }\end{array}$ & $\begin{array}{l}\text { (2R,3S,4S,5R)-2-(6-amino-9H-purin-9-yl)- } \\
\text { 5-(hydroxymethyl)oxolane-3,4-diol } \\
\text { hydrate }\left[\mathrm{C}_{10} \mathrm{H}_{15} \mathrm{~N}_{5} \mathrm{O}_{5}\right]\end{array}$ & $\begin{array}{l}\text { Antiviral Viral DNA polymerase } \\
\text { inhibitor/substrate }\end{array}$ \\
\hline $\begin{array}{l}\text { iota-Carrageenan [Carragelose }{ }^{\circledR} \text { ] } \\
\text { Source: Eucheuma denticulatum } \\
\text { Phylum: Rhodophyta Class: } \\
\text { Florideophyceae }\end{array}$ & A family of linear sulfated polysaccharides & Antiviral \\
\hline $\begin{array}{l}\left.\text { Omega-3[Lovaza }{ }^{\circledR}\right] \text { Source: oil of } \\
\text { several fish sources }\end{array}$ & $\begin{array}{l}\text { Omega-3-acid ethyl esters (ethyl } \\
\text { esters of eicosapentaenoic acid (EPA) } \\
\text { and docosahexaenoic acid (DHA)) } \\
\text { EPA ethyl ester: }\left[\mathrm{C}_{22} \mathrm{H}_{34} \mathrm{O}_{2}\right] \text { DHA } \\
\text { ethyl ester: }\left[\mathrm{C}_{24} \mathrm{H}_{36} \mathrm{O}_{2}\right]\end{array}$ & $\begin{array}{l}\text { Hypertriglyceridemia Adjunct to } \\
\text { diet to reduce triglyceride (TG) } \\
\text { levels in adult patients with severe } \\
\text { ( } \geq 500 \mathrm{mg} / \mathrm{dL} \text { ) } \\
\text { hypertriglyceridemia (HTG). } \\
\text { Increased breakdown of fatty } \\
\text { acids; inhibition of diglyceride } \\
\text { acyltransferase which is involved } \\
\text { in biosynthesis of triglycerides in } \\
\text { the liver; and increased activity of } \\
\text { lipoprotein lipase in blood }\end{array}$ \\
\hline
\end{tabular}

Lovaza $^{\circledR}$, obtained by fish oil, is an $\Omega$-3-acid ethyl esters (ethyl esters of eicosapentaenoic acid (EPA) and docosahexaenoic acid (DHA)), authorized as an adjunct to diet to reduce triglyceride (TG) levels in adult patients with severe ( $\geq 500 \mathrm{mg} / \mathrm{dL}$ ) hypertriglyceride (HTG) [19]. Different mechanisms of action have been proposed for $\Omega$-3-acid ethyl esters including inhibition of diacylglycerol acyltransferase, increased plasma lipoprotein lipase activity, decreased hepatic lipogenesis, and increased hepatic $\beta$-oxidation [19].

This review describes various compounds of natural marine sources able to modulate several different anti-obesity targets. With the exception of fish oil drug derivatives approved by FDA/EMA all the compounds are in preclinical setting (cell and animal models) and need further experiments to make clear the mechanism of action, the possible side effects and the safety. A possible link between anti-obesity activity and lung function modification is hypothesized. Compounds from marine organisms containing EPA and DHA are not described in detail in this review since there is a copious literature see the recent reviews [19-23].

\section{COPD and Obesity}

Traditionally, COPD is associated with sarcopenia (a condition characterized by loss of skeletal muscle mass and function, frequently occurring in advance age) [24]. However, obesity is currently frequent in COPD, contributing to respiratory symptoms [25] and potentiating several known 
associated comorbidities such as cardiovascular disease (CVD), type2-diabetes (T2DM), skeletal muscle dysfunction, and obstructive sleep apnea [26]. The occurrence of COPD with sarcopenia and concurrent obesity (i.e., Sarcopenic Obesity: SO) has recently been reported [27]. A study that evaluated 2000 patients with COPD shows that the presence of SO induces worse physical performance and higher systemic inflammatory burden than in patients with COPD alone [27]. The concomitant presence of COPD and obesity is rising at a remarkable rate in the Western world [28]. In these patients, the respiratory symptoms have the tendency to be worst, the daily activities are more restricted and the quality of life $(\mathrm{QoL})$ is poorer than in non-obese subjects. A recent study, examined 3631 COPD patients with a confirmed post-bronchodilator $\mathrm{FEV}_{1}<80 \%$ predicted and a Body Mass Index $(\mathrm{BMI}) \geq 18.5 \mathrm{~kg} / \mathrm{m}^{2}$ to test the hypothesis of the association between obesity and worse outcomes in COPD. In the above study, the association between obesity and worse outcomes was independent of the presence of comorbidities and was associated, in a dose-dependent manner, with worse QoL, dyspnea, endurance to six minutes walking distance (6 MWD) and severe acute exacerbation of COPD (AECOPD). These associations were strengthened when obesity was analyzed as a dose-dependent response [29]. On the other hand, in a not fully understood reason, obesity seems associated with a reduced mortality risk in COPD patients (so-called "COPD-obesity paradox") [30]. A recent study, planned to explain the "COPD-obesity paradox", assessed the causal role of high $\mathrm{BMI}$ in COPD exacerbations and pneumonias [31]. Authors analyzed the genetic variants that cause lifelong high BMI in FTO (fat mass and obesity-associated gene, rs9939609), MC4R (Melanocortin-4 Receptor gene, rs17782313) and TMEM18 (transmembrane protein 18, rs6548238) genes to evaluate the consequences of the obesity in COPD patients. The study evaluates a large cohort population of the Copenhagen General Population Study, including 10,883 subjects who had spirometric (FEV 1 measurement) COPD. The study concludes that genetically determined high BMI is associated with an increased risk of recurrent exacerbations and pneumonias in individuals with COPD, while this was not the case for observationally determined high BMI [31].

It has been suggested that adipose tissue may talk to other organs through endocrine functions; specifically, the crosstalk between adipose tissue and lung may be mediated by adipokines [32]. Thus, the serum levels of adipokines are elevated in patients affected by COPD, independently of their smoking habit, and positively correlate with disease severity and ratio of exacerbation [33,34]. Moreover, high adiponectin levels and low leptin/adiponectin ratio are associated with annual forced expiratory volume in $1 \mathrm{~s}\left(\mathrm{FEV}_{1}\right)$ decline [33].

Adiponectin plays a key role in carbohydrate and fat metabolism. It is a polypeptide of $30 \mathrm{kDa}$, expressed and released exclusively from adipocytes of white adipose tissue. Adiponectin acts throughout two principal receptors, AdipoR1 and AdipoR2, activating or inhibiting down-stream signaling pathways such as AMPK and ceramidase (activation) or phosphatidylinositol 3-kinase; wing-less type protein (Wnt)/ $\beta$-catenin, ERK1/2; nicotinamide adenine dinucleotide phosphate oxidase, STAT3; and nuclear factor $\mathrm{\kappa B}(\mathrm{NF} \kappa \mathrm{B})$ (inhibition). Adiponectins secretion is stimulated by insulin and inhibited by TNF and IL-6. Secretion of the hormone decreases in the case of obesity $[35,36]$. Leptin regulates fat mass, food intake, and thermogenesis enhancing the production of TNF and IL-6. It also promotes the production of reactive oxygen species (ROS), and stimulates monocytes proliferation and migration [37].

Obesity is a complex metabolic disorder in which interactions among genetic/epigenetic, behavioral and environmental factors lead to its development. The World Health Organization (WHO) defines obesity as: "BMI equal to or greater than $30 \mathrm{~kg} / \mathrm{m}^{2}$ " [38]. Phenotypically, accumulation of fat in different body regions (principally abdominal) characterizes obesity, while, at the cellular level, obesity implies both an increase in the adipocyte cell size (hypertrophy) and an increase in the adipocyte cell number (hyperplasia) [39]. Actually, diet plays a major role in the probability to develop a chronic disease (better called as non-communicable diseases (NCDs)), especially in the presence of unhealthy habits or overweight. Obesity is a well-known risk factor of increased premature mortality and cardiovascular disease, diabetes, and cancer [40]. The worldwide incidence of 
obesity doubled over the past decades, leading to increasing rates of diabetes mellitus, cardiovascular disease, and their complications. For adults, WHO defines overweight and obesity as follows: overweight is a BMI greater than or equal to 25; while obesity is a BMI greater than or equal to 30 [41]. According to the different class of obesity, people with class 1 (BMI $\geq 30$ and $\leq 35$ ) do not have elevated healthcare costs, but for people in the range of class 2 and 3 (BMI $\geq 35$ ) the healthcare costs rise rapidly in parallel with BMI. The major expenditure is strictly linked to concomitant diseases. It has been estimated that a 5\% reduction in weight allows a savings in annual medical care of \$US2137 for those subjects with a starting BMI of 40, of \$US528 for those of 35, and \$US69 for those of 30 [42]. The extensive application of omics-based technologies allows establishing what factors may influence health status, disease development, and an individual's response to interventions. Metabolomics, that measures the complete balance of metabolites, may be particularly influential in this respect. Indeed, the notion of a personal metabolic phenotype or "metabotype" was coined with the introduction of metabolomics-based research [43,44]. Metabolomics may identify metabolite profiles and biological pathways associated with diet-related diseases [45] and may help in unraveling the relationships between health and disease status (Figure 3), thus among metabolism, obesity and progression of COPD. At the same time, metabolomics may have potential as a clinical tool in risk evaluation and monitoring of disease [46].

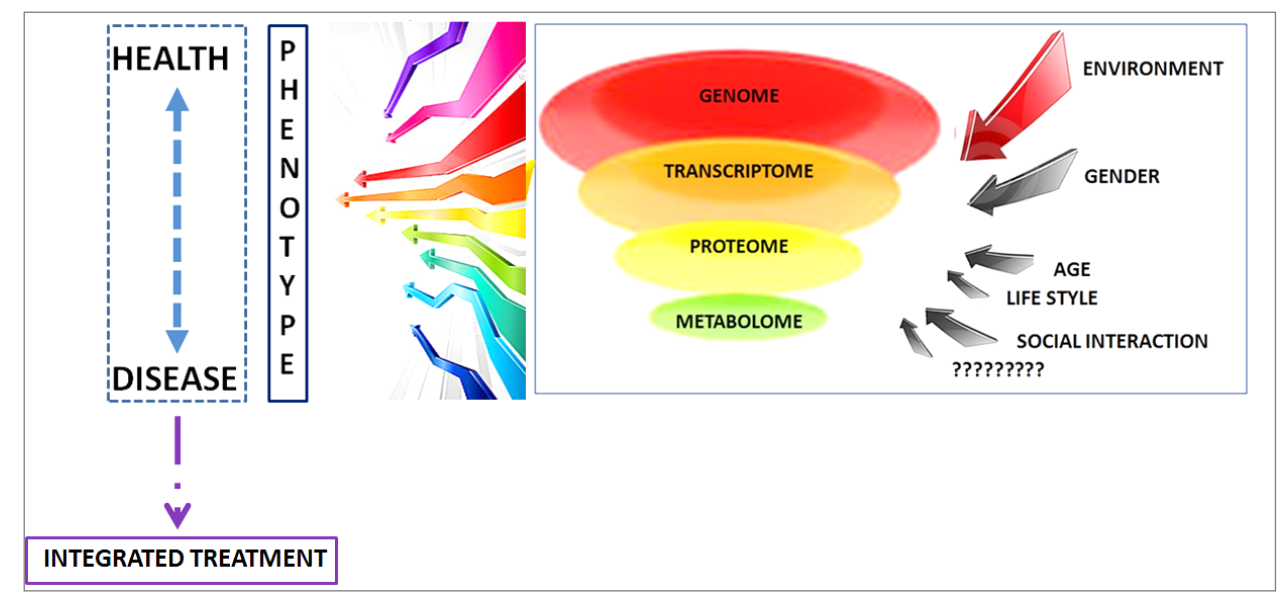

Figure 3. Interaction between omics and environment to determine phenotype health/disease.

\section{Treatment of Obesity}

Until now, no safe and effective anti-obesity drugs that include suppressing appetite, drugs increasing insulin sensitivity, drugs targeting sodium/glucose cotransporters and drugs decreasing lipid absorption have been developed. The FDA, in approving an anti-obesity drug, requires a weight reduction of at least $5 \%$ for at least one year (difference between the drug and the placebo groups) in the $35 \%$ subjects in treatment $[47,48]$. The newest drug Saxenda ${ }^{\circledR}$ (liraglutide, rDNA origin) $[49,50]$ is approved by FDA/EMA as "a treatment option for chronic weight management in addition to a reduced-calorie diet and physical activity to subject who also have one or more complications related to their weight, such as type 2 diabetes, high blood pressure, high cholesterol or obstructive sleep apnea". Saxenda ${ }^{\circledR}$ is a glucagon-like peptide-1 (GLP-1) receptor agonist. EMA recommended that whenever a patient does not lose $5 \%$ of their initial body weight after 13 weeks, the treatment with Saxenda ${ }^{\circledR}$ should be stopped [50]. As a general observation, every success on pharmacotherapy of weight management is not related with any changes to the obesity cellular/molecular mechanisms and is transitory. The success of pharmacotherapy depends on personalizing treatment considering genetics, behaviors and comorbidities and consequently drug interactions, contraindications, and risk of potential adverse effects. 


\section{Marine Drugs and Obesity and COPD}

All over the world, natural products have been the source of food and medicine. Nowadays, ocean habitats are the newest frontier in drug medical research. Since 1969, FDA/EMA have approved eight drugs of marine origin (Figure 2) including important anticancer agents. Although the actualization of this area of scientific exploration is relatively new, the first testimony of marine medicine comes from 2953 BC during emperor Fu His in China as a tax for profits of fish-derived medicine [51]. Indeed, fish oils are marine-derived products that have been in use for millennia. Actually, several reviews on this topic have been published [52-58]. Different marines organisms (from fishes such as salmon and herring, to krill and squid) contain so-called "marine $\omega-3$ fatty acids" and specifically eicosapentaenoic acid (EPA; 20:5n-3), docosapentaenoic acid (DPA; 22:5n-3) and docosahexaenoic acid (DHA; 22:6n-3) [59]. Both EPA and DHE control metabolism and functions of adipose tissue, supporting the oxidative metabolism via mitochondrial biogenesis and fatty acid oxidation. EPA and DHA also regulate adipocyte glucose utilization and insulin sensitivity (Akt phosphorylation) through Peroxisome proliferator-activated receptor gamma (PPAR $\gamma$ ) and $5^{\prime}$ adenosine monophosphate-activated protein kinase (AMPK) activation. EPA and DHA regulating the production of pro-inflammatory chemokines and cytokines may reduce inflammation. In 2001 and 2004, Lovaza ${ }^{\circledR} /$ Omacor $^{\circledR}$, a drug containing EPA and DHE, was approved by EMA and FDA [60], respectively, as a lipid-regulating agent. Presently, an ancillary study (R01HL101932 supported by the National Heart Lung and Blood Institute (NHLBI)) is ongoing on a subset of participants in Vitamin D and Omega-3 Hypertension Trial (VITAL Hypertension) (VITAL; NCT 01169259 a five-year U.S.-wide randomized, double-blind, placebo-controlled) with the aim to examine whether marine $\omega-3$ fatty acids $\left(\mathrm{Omacor}^{\circledR} 1 \mathrm{~g} /\right.$ day) improves respiratory symptoms or reduces the risk of lung infections or reduces the decline of pulmonary function [61]. The VITAL-subcohort was initially composed of 2027 participants of both gender, 50 years and older (adult, senior), from 11 continental U.S. locations. In total, 1973 subjects were randomized and 1924 had lung function tests of acceptable quality, among these 27.3\% had mild or moderate Global Initiative for Chronic Obstructive Lung Disease (GOLD) COPD stages and 5.9\% had PRISm (Preserved Ratio Impaired Spirometry or "restrictive" spirometry) [61]. Interestingly, the mean BMI of the subjects entering on the study was 29.9 ( $>30=$ obesity) suggesting overweight or obesity.

EPA and DHA control adipose tissue metabolism and functions acting on:

- Adipocyte fat storage and mobilization;

- Adipocyte oxidative metabolism through the stimulation of mitochondrial biogenesis and fatty acid oxidation;

- Adipocyte glucose utilization and insulin sensitivity (Akt phosphorylation);

- Secretion of adipokines; and

- Mitigation of adipose tissue inflammation through production of pro-inflammatory chemokines/cytokines, reduction of M1 macrophage infiltration/-6 derived pro-inflammatory lipid mediators production, being substrates for the formation of some specialized pro-resolving lipid mediator (SPMs), namely resolvins, protectins, and maresins.

SPMs, acting throughout specific 7-transmembrane G-protein coupled receptors, take action on neutrophil trafficking, promote macrophage phagocytosis, and block pro-inflammatory cytokine and chemokine production. In human, 15-lipoxygenase produces protectins and resolvins D while, resolvin E series are produced via the acetylated cyclooxygenase- 2 or cytochrome P450 pathway. The levels of SPMs in COPD are lower than in non-affected patients suggesting that a scarce activity of SPMs may maintain the status of chronic inflammation and is a cause of the pathobiology of COPD [23]. Figure 4 summarizes possible mechanisms linking the effects of EPA/DHA on adipose tissues and on lung functions. 


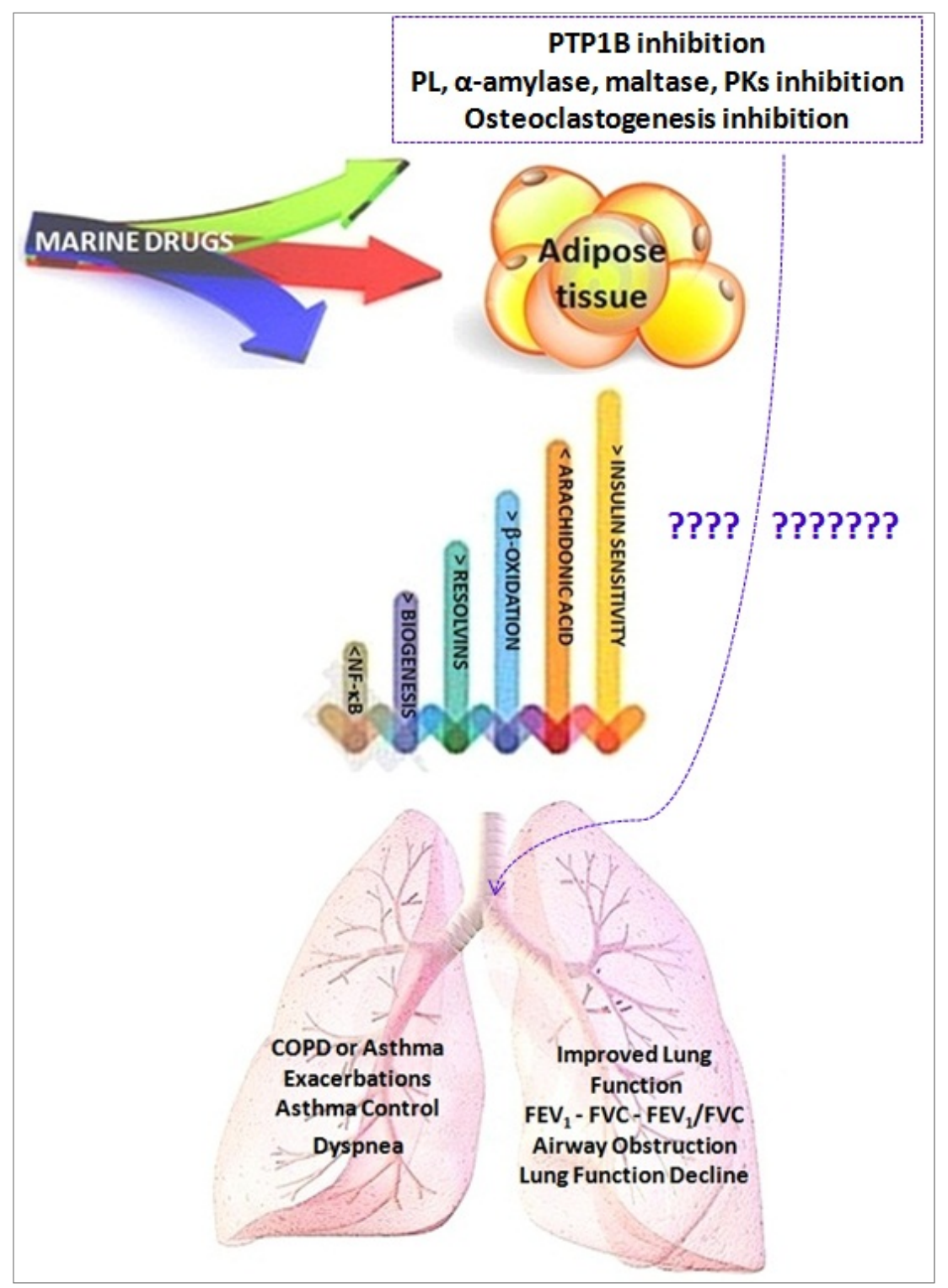

Figure 4. Relationship between adipose tissue and lung function after DHA/EPA administration. Adapted from [23,61]. Protein tyrosine phosphatase 1B (PTP1B); Pancreatic lipase (PL); Protein kinases (PKs).

Table 2 reports new drugs and drug derivatives obtained by different marine organisms proposed in anti-obesity treatment [62-94]. 
Table 2. Marine organisms and drug derivatives for anti-obesity treatment.

\begin{tabular}{|c|c|c|c|}
\hline \multicolumn{4}{|c|}{ CRUSTACEAN Phylum: Arthropoda } \\
\hline Source & Drug & Target and Activity & Reference \\
\hline Euphausia superb & $\begin{array}{l}\text { Eicosapentaenoic acid } \\
\text { (EPA) \& Docosahexaenoic } \\
\text { acid (DHA) (krill oil) }\end{array}$ & $\begin{array}{l}\text { Randomized, double-blind parallel arm trial, overweight and obese } \\
\text { men and women }(n=76) \text { were randomly assigned to receive } \\
\text { double-blind capsules containing } 2 \text { g/day of krill oil, menhaden oil, } \\
\text { or control (olive) oil for } 4 \text { weeks. Plasma EPA and DHA concentrations } \\
\text { increased significantly more in the krill oil groups than in the } \\
\text { control group.Well tolerated, with no indication of adverse effects on } \\
\text { safety parameters. Reduced body weight gain, abdominal fat, and liver } \\
\text { triacylglycerol on diet-induced obese mice }\end{array}$ & {$[62,63]$} \\
\hline Calanus finmarchicus & $\begin{array}{l}\text { Wax ester component of } \\
\text { Calanus oil = PUFAs }\end{array}$ & $\begin{array}{l}\text { On diet-induced obesity and obesity-related disorders in mice. } \\
\text { C57BL/6J mice fed a high-fat diet (HFD, } 45 \% \text { energy from fat) reduced } \\
\text { body-weight gain, abdominal fat accumulation and hepatic steatosis } \\
\text { and improved glucose tolerance Calanus oil supplementation reduced } \\
\text { adipocyte size and increased the mRNA expression of adiponectin in } \\
\text { adipose tissue. It also reduced macrophage infiltration accompanied by } \\
\text { reduced mRNA expression of pro-inflammatory cytokines (TNF- } \alpha \text {, IL-6 } \\
\text { and monocyte chemotactic protein-1) }\end{array}$ & {$[64,65]$} \\
\hline \multicolumn{4}{|l|}{ SPONGES Phylum: Porifera } \\
\hline Source & Drug & Target and Activity & Reference \\
\hline Axinyssa sp. & $\begin{array}{l}N, N^{\prime} \text {-bis }[(6 R, 7 S)-7 \text {-amino- } \\
7,8 \text {-dihydro- } \alpha \text {-bisabolen-7- } \\
\text { yl]urea }\end{array}$ & $\begin{array}{l}\text { Protein tyrosine phosphatase 1B (PTP1B) inhibitor. Enhances the } \\
\text { insulin-stimulated phosphorylation levels of Akt in Huh-7 human } \\
\text { hepatoma cells }\end{array}$ & {$[66]$} \\
\hline Euryspongia sp. & Dehydroeuryspongin A & Protein tyrosine phosphatase $1 \mathrm{~B}(\mathrm{PTP} 1 \mathrm{~B})$ inhibition at $\mathrm{IC}_{50}=3.58 \mu \mathrm{M}$ & [67] \\
\hline \multirow{2}{*}{ Xestospongia testudinaria } & \multirow{2}{*}{$\begin{array}{l}\text { Xestonarienes A-HNew } \\
\text { steroidal ketone with } \\
\text { an ergosta-22,25-diene } \\
\text { side chain }\end{array}$} & $\begin{array}{l}\text { Pancreatic lipase }(\mathrm{PL}) \text { inhibition } \mathrm{IC}_{50}=3.11 \mu \mathrm{M} \text {. Decrease in the plasma } \\
\text { triglyceride level following an oral lipid challenge in C } 57 \mathrm{BLKS} / \mathrm{J} \\
\text { male mice }\end{array}$ & {$[68,69]$} \\
\hline & & $\begin{array}{l}\text { Protein tyrosine phosphatase } 1 \mathrm{~B}(\mathrm{PTP} 1 \mathrm{~B}) \text { inhibition } \\
\mathrm{IC}_{50} \text { value }=4.27 \pm 0.55 \mu \mathrm{M}\end{array}$ & [70] \\
\hline Heterofibria & $\begin{array}{l}\text { Fatty acids heterofibrins } \\
\text { A1 \& B1 possessing } \\
\text { a diyne-ene moiety }\end{array}$ & Lipid droplet formation inhibition in A431 fibroblast cell lines & \\
\hline
\end{tabular}


Table 2. Cont.

Protein tyrosine phosphatase 1B (PTP1B) inhibition with

an $\mathrm{IC}_{50}=42 \mu \mathrm{M}$ in a noncompetitive inhibition mode enhances the

membrane translocation of the key glucose transporter Glut4 in

PTP1B-overexpressed CHO cells facilitate insulin inhibition of Smad2 activation through the PI3K/AKT pathway

Adipogenic differentiation inhibition as indicated by less fat droplets and decreased expression of adipogenic marker genes. The expression of TAZ (transcriptional coactivator with PDZ-binding motif Phorbaketal [72]

A increased the interaction of TAZ and PPAR $\gamma$ to suppress PPAR $\gamma$

Phorbas sp.

Phorbaketal A

(tricyclic sesterterpenoid) (peroxisome proliferator-activated receptor $\gamma$ ) target gene expression

Inhibits the production of inflammatory mediators via down-regulation of the of nuclear factor-kappaB (NF- $\mathrm{kB})$, pathway and up-regulation of the heme oxygenase-1 (HO-1) system in LPS-stimulated RAW 264.7

macrophage cells

\begin{tabular}{|c|c|c|c|}
\hline Dysidea villosa & $\begin{array}{l}\text { Dysidine } \\
\text { (sesquiterpene quinine) }\end{array}$ & $\begin{array}{l}\text { Differentiated 3T3-L1 cells and resulted in the increased deposition of } \\
\text { Glucose transporter type } 4 \text { (GLUT4) in the cellular membrane }\end{array}$ & {$[74]$} \\
\hline Theonella sp. & $\begin{array}{l}\text { 4-methylenesteroid } \\
\text { derivativesconicasteroland } \\
\text { heonellasterol) }\end{array}$ & $\begin{array}{l}\text { Pregnane-X-receptor (PXR) modulators PXR is a gene involved in the } \\
\text { bilirubin, bile acids, glucose and lipids metabolism }\end{array}$ & {$[75]$} \\
\hline \multicolumn{4}{|c|}{ TUNICATES Phylum: Chordata (sub-Phylum: Tunicata) } \\
\hline Source & Drug & Target and Activity & Reference \\
\hline Aplidium meridianum & $\begin{array}{l}\text { Meridianin C derivatives } \\
\text { (indole alkaloids) }\end{array}$ & $\begin{array}{l}\text { Inhibition lipid accumulation during 3T3-L1 pre-adipocyte } \\
\text { differentiation and lowered leptin expression it influences important } \\
\text { differentiation pathways as C/EBP- } \alpha \text {, PPAR } \gamma \text { and fatty acid synthase }\end{array}$ & {$[76]$} \\
\hline \multicolumn{4}{|c|}{ ECHINODERM Phylum: Echinodermata } \\
\hline Source & Drug & Target and Activity & Reference \\
\hline Stichopus japonicas & $\begin{array}{l}\text { 1,3-Dipalmitolein \& } \\
\text { cis-9-octadecenoic acid }\end{array}$ & $\begin{array}{l}\alpha \text {-Glucosidase inhibitors in Saccharomyces cerevisiae } \mathrm{IC}_{50}=4.45 \text { and } \\
14.87 \mu \mathrm{M}\end{array}$ & {$[77]$} \\
\hline
\end{tabular}


Table 2. Cont

\begin{tabular}{|c|c|c|c|}
\hline ALGAE Phylum: Euglenozoa & & & \\
\hline Source & Drug & Target and Activity & Reference \\
\hline \multirow{5}{*}{$\begin{array}{l}\text { Undaria pinnati fida, } \\
\text { Laminaria japonica } \\
\text { (macroalgae, brown seaweeds) \& } \\
\text { Cylindrotheca closterium (microalgae) }\end{array}$} & \multirow{5}{*}{ Fucoxanthin } & $\begin{array}{l}\text { Induces uncoupling protein } 1 \text { (UCP1) in abdominal white adipose } \\
\text { tissue (WAT) mitochondria, leading to the oxidation of fatty acids and } \\
\text { heat production in WAT regulation of cytokine secretions from both } \\
\text { abdominal adipose cells and macrophage cells infiltrated into } \\
\text { adipose tissue }\end{array}$ & {$[78,79]$} \\
\hline & & $\begin{array}{l}\text { Regulates mRNA expression of inflammatory adipocytokines involved } \\
\text { in insulin resistance, iNOS, and COX-2 in WAT and has specific effects } \\
\text { on diabetic/obese KK-A(y) mice, but not on lean C57BL/6J mice }\end{array}$ & {$[80,81]$} \\
\hline & & $\begin{array}{l}\text { Inhibits lipase activity in the gastrointestinal lumen and suppress } \\
\text { triglyceride absorption, and fucoxanthin was converted to } \\
\text { fucoxanthinol in the intestine and released into the lymph in } \\
\text { conscious rats }\end{array}$ & {$[82]$} \\
\hline & & $\begin{array}{l}\text { Fucoxanthin upregulates the expression of uncoupling protein } 1 \text { (UCP1) } \\
\text { and adipokine mRNA in white adipose tissue (WAT) of diabetic/obese } \\
\text { KK-A(y) mice }\end{array}$ & [83] \\
\hline & & $\begin{array}{l}\text { Down-regulates SCD1 expression and alters fatty acid composition of } \\
\text { the liver via regulation of leptin signaling in hyperleptinemia KK-A(y) } \\
\text { mice but not in leptin-deficient ob/ob mice }\end{array}$ & [84] \\
\hline \multirow[t]{2}{*}{ Ecklonia stolonifera (brown algae) } & \multirow[t]{2}{*}{$\begin{array}{l}\text { Fucoxanthinol/ } \\
\text { Fucoxanthin Metabolite }\end{array}$} & $\begin{array}{l}\text { 3T3-L1 adipocyte cells and a RAW264.7 macrophage cell co-culture } \\
\text { system. A diet containing 0.1\% Fx was fed to diabetic model KK-Ay } \\
\text { mice for three weeks Fx diet significantly improved glucose tolerance } \\
\text { compared with the control diet group.In in vitro studies, FxOH showed } \\
\text { suppressed tumor necrosis factor- } \alpha \text { (TNF- } \alpha \text { ), and monocyte chemotactic } \\
\text { protein-1 (MCP-1) mRNA expression and protein levels in a co-culture } \\
\text { of adipocyte and macrophage cells }\end{array}$ & {$[85]$} \\
\hline & & $\begin{array}{l}\text { Inhibits expression of PPAR } \gamma \text { and } \mathrm{C} / \mathrm{EBP} \alpha \text {, resulting in a decrease of } \\
\text { lipid accumulation in 3T3-L1 pre-adipocytes,3T3-L1 pre-adipocytes } \\
\text { differentiation }\end{array}$ & [86] \\
\hline
\end{tabular}


Table 2. Cont

\begin{tabular}{|c|c|c|c|}
\hline \multicolumn{4}{|l|}{ ALGAE Phylum: Euglenozoa } \\
\hline Source & Drug & Target and Activity & Reference \\
\hline Eisenia bicyclis (brown algae) & 6,6'-bieckol & $\begin{array}{l}\text { Decreased lipid accumulation and expression levels of peroxisome } \\
\text { proliferator-activated receptor } \gamma(\mathrm{PPAR} \gamma) \text {, CCATT/enhancer-binding } \\
\text { protein } \alpha(\mathrm{C} / \mathrm{EBP} \alpha) \text { and sterol regulatory element binding protein-1c } \\
\text { (SREBP-1c) (mRNA and protein), and fatty acid synthase and acyl-coA } \\
\text { carboxylase (mRNA). inhibition of differentiation of 3T3-L1 adipocytes }\end{array}$ & [87] \\
\hline Ulva lactuca & $\begin{array}{l}\text { Ulva lactuca } \\
\text { polysaccharides (ULPS) }\end{array}$ & $\begin{array}{l}\alpha \text {-amylase and maltase inhibition leading to a significant decrease in } \\
\text { blood glucose rate }\end{array}$ & {$[88]$} \\
\hline Phaeodactylum tricornutum & Fucosterol & $\begin{array}{l}\text { C57BL / } 6 \text { mice a high-fat diet supplemented with PT powder }(15 \% \text { or } \\
30 \% w / v) \text { for } 12 \text { weeks, and determined energy intake, weight loss, } \\
\text { and lipid profiles each week reduced body weight gain, and epididymal } \\
\text { and perirenal adipose tissue weight via activation of AMPK and } \\
\text { HMGCR pathways }\end{array}$ & [89] \\
\hline \multirow[t]{3}{*}{ Hematococcus pluvialis } & \multirow[t]{3}{*}{ Astaxanthin } & $\begin{array}{l}\text { Male Swiss albino mice: starch-based control diet or a high fat-high } \\
\text { fructose diet (HFFD). Fifteen days later, mice in each dietary group were } \\
\text { divided into two and were treated with either ASX }\left(6 \mathrm{mg} \cdot \mathrm{kg}^{-1} \text { per day) }\right. \\
\text { in olive oil or olive oil alone. For } 60 \text { days ASX treatment reduced lipid } \\
\text { levels and oxidative stress in skeletal muscle and adipose tissue and } \\
\text { improved insulin signaling by enhancing the autophosphorylation of } \\
\text { insulin receptor- } \beta \text { (IR- } \beta \text { ), IRS-1 associated PI3-kinase step, } \\
\text { phospho-Akt/Akt ratio and GLUT- } 4 \text { translocation in skeletal muscle }\end{array}$ & [90] \\
\hline & & $\begin{array}{l}\text { Pre-treatment with ASTA }(10 \mu \mathrm{M}) \text { for } 1 \mathrm{~h} \text { attenuates the LPS-induced } \\
\text { toxicity and ROS production. In U937 cells stimulated with LPS } \\
(10 \mu \mathrm{g} / \mathrm{mL})\end{array}$ & [91] \\
\hline & & $\begin{array}{l}\text { Astaxanthin inhibited the increases in body weight and weight of } \\
\text { adipose tissue that result from feeding mice a high-fat diet, reduced } \\
\text { liver weight, liver triglyceride, plasma triglyceride, and total cholesterol }\end{array}$ & [92] \\
\hline
\end{tabular}


Table 2. Cont

\begin{tabular}{|c|c|c|c|}
\hline \multicolumn{4}{|l|}{ FUNGI Phylum: Ascomycota } \\
\hline Source & Drug & Target and Activity & Reference \\
\hline Penicillium spp. Eurotium sp. & $\begin{array}{l}\text { Fructigenine A } \\
\text { Cyclopenol Echinulin } \\
\text { Flavoglaucin Viridicatol }\end{array}$ & $\begin{array}{l}\text { Selective inhibition of PTP1B fructigenine A in a noncompetitive } \\
\text { manner, viridicatol in a competitive manner }\end{array}$ & {$[93]$} \\
\hline \multicolumn{4}{|c|}{ CYANOBACTERIA Phylum: Cyanobacteria } \\
\hline Source & Drug & Target and activity & Reference \\
\hline Leptolyngbya sp. & $\gamma$-pyrones yoshinone & $\begin{array}{l}\text { Osteoclastogenesis, protein kinase inhibitor. Inhibitory activity against } \\
\text { the adipogenic differentiation of 3T3-L1 cells } \mathrm{IC}_{50}=420 \mathrm{nM} \text {. Mice at } \\
\text { high-fat diet (HFD) for } 5 \text { weeks received kalkipyrone at a dosage of } \\
5 \mathrm{mg} \cdot \mathrm{kg}^{-1} / \text { day showed effective suppression of adipose tissue weight } \\
\text { gain in mice }\end{array}$ & [94] \\
\hline
\end{tabular}


With the exception of the Antarctic krill oil [62,63], containing EPA + DHA, which was studied on human, all compounds, reported in Table 1, are in preclinical setting. Indeed, a randomized, double-blind parallel arm trial study, on overweight and obese men and women $(n=76)$ receiving $2 \mathrm{~g} /$ day of krill oil, or olive oil for four weeks concludes that krill oil supplementation increases plasma EPA and DHA, and is well tolerated, without adverse effects [62]. The subsequent study showed that $2 \mathrm{~g} /$ day of krill oil, for four week, increases the concentration of plasma endocannabinoids in overweight and obese subjects but decreases 2-arachidonoylglycerol (2-AG), only in obese subjects [63]. According to these studies no effects on MetD are produced by krill oil, further researches are warranted. As shown in Table 1, only compounds produced by Calanus finmarchicus, Phorbas sp., Aplidium meridianum, Undaria pinnati fida, Laminaria japonica, Cylindrotheca closterium, and Hematococcus pluvialis act specifically on adipose tissue, while other marine drugs target systems beyond the adipose tissue. Drugs from Axinyssa sp., Eurispongia sp., Xestospongia testudinaria, Hyrtios erectus, Penicillium and Eurotium sp. selectively inhibit the Protein tyrosine phosphatase 1B (PTB1B). PTB1B regulates negatively Tyrosine Kinase Receptors-signaling, especially the insulin and leptin receptors [95]. As reported above, low leptin/adiponectin ratios are associated with annual forced expiratory volume in $1 \mathrm{~s}$ (FEV1) decline [33]. It has been shown that in women suffering from COPD leptin metabolism is altered with higher secreted leptin levels per BMI strata than in men suffering from COPD [96] It is possible to postulate that leptin secretion increase as well as a gender-dependent dysregulation of adipokine metabolism in patients with COPD compared with BMI-matched controls [97] may contribute to sex differences in COPD pathogenesis through a pathway of chronic systemic inflammation. Women patients may benefit from a treatment that reduces leptin overproduction.

Figure 5 shows the molecular structures of drugs in Table 2.

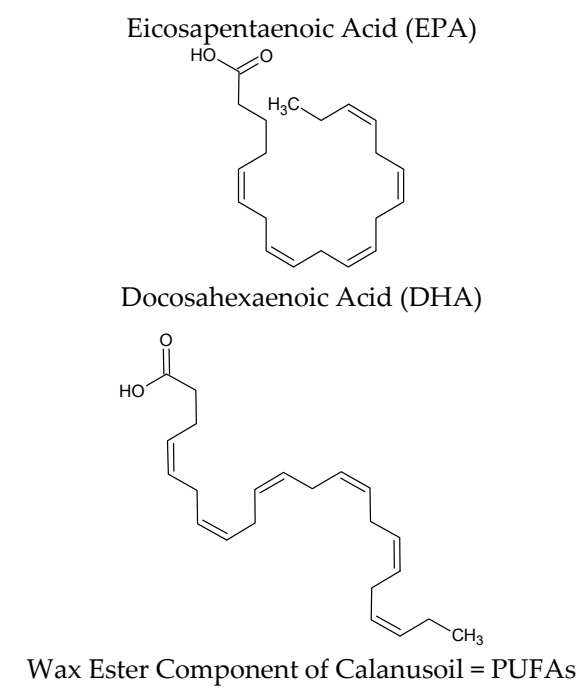

A Typicalwaxester in calanusoil with the polyunsaturatedomega-3 fatty acid SDA (18:4n-3) and long-chainmonounsaturatedalcohol (22:1n-11) waxesters from the marine copepod Clanus finmarchicusreduce diet-inducedobesity and obesity-relatedmetabolicdisorders in mice.

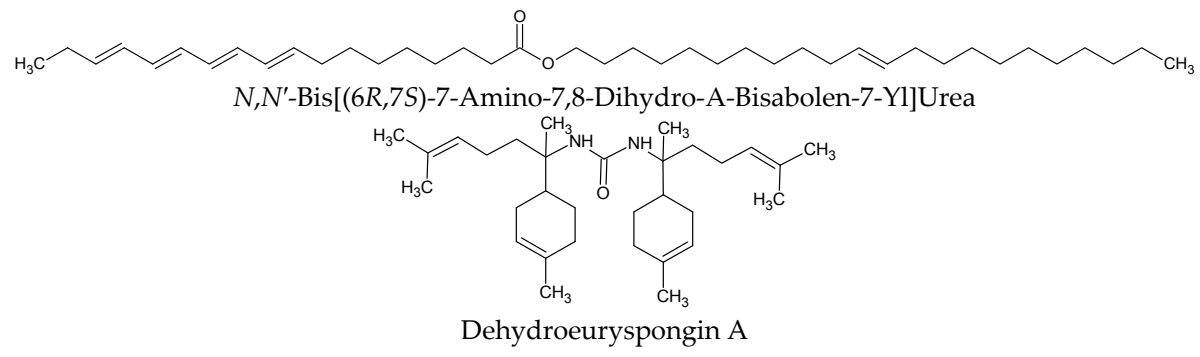

Figure 5. Cont. 


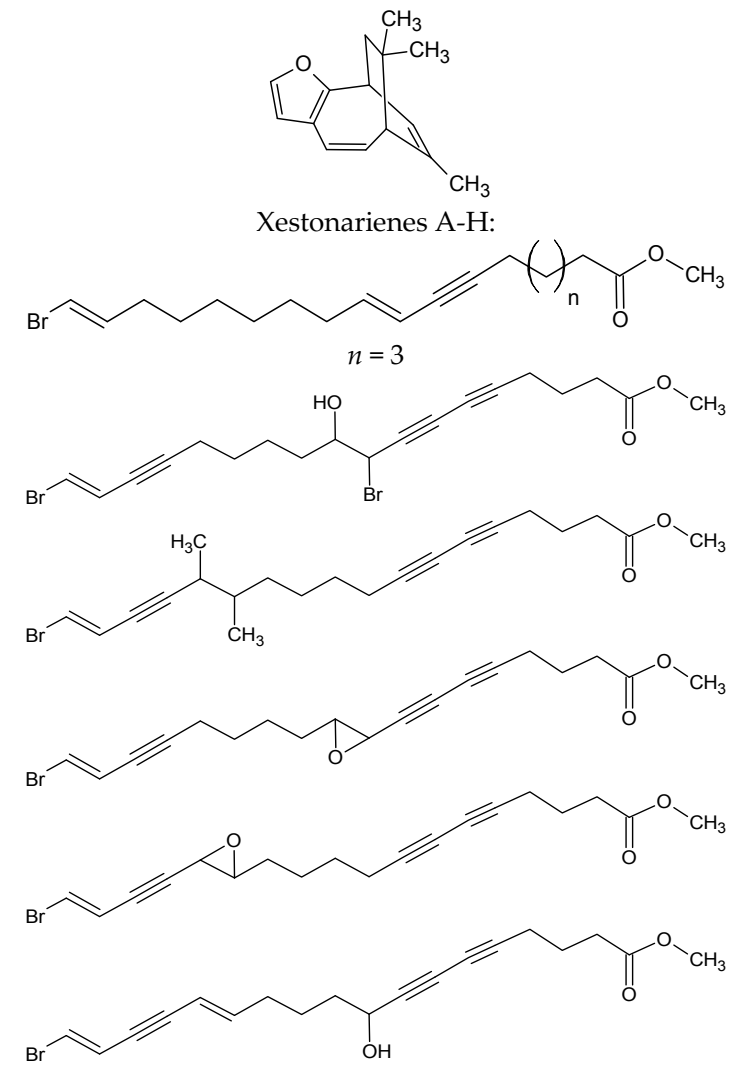

Fatty acids heterofibrins $\mathrm{A} 1$ and $\mathrm{B} 1$ possessing adiyne-ene moiety:
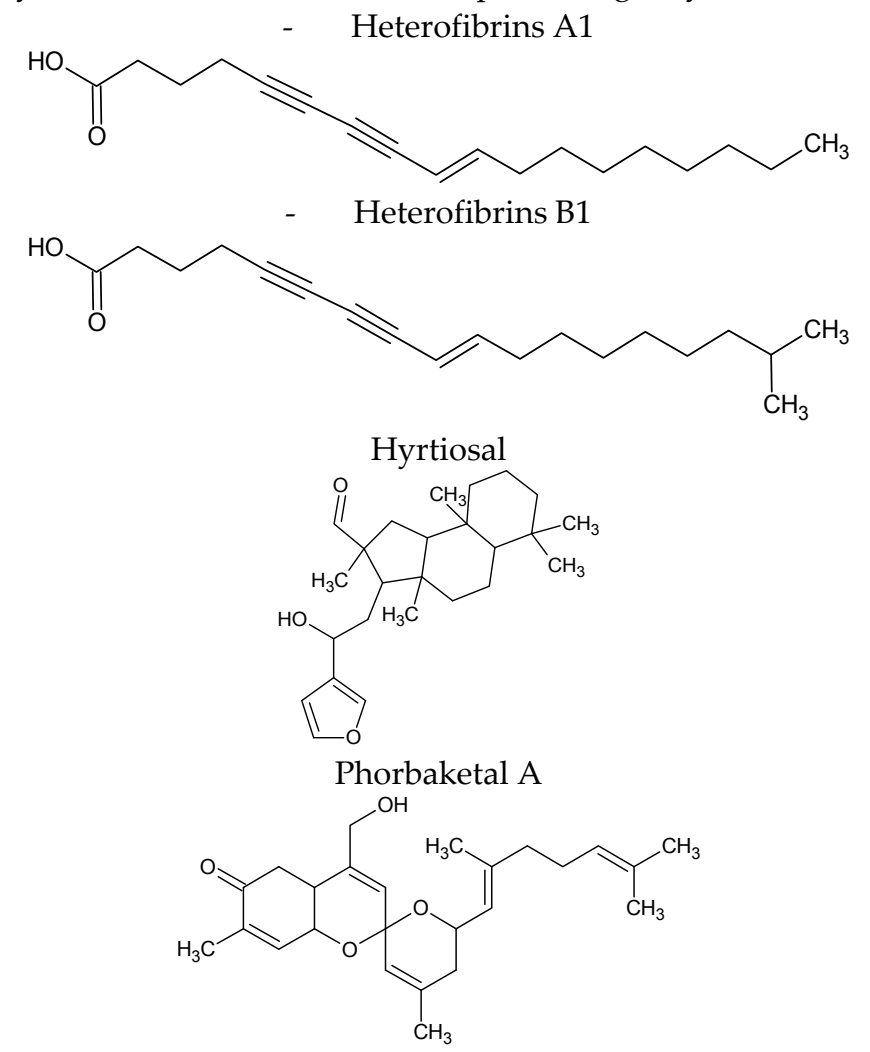

Figure 5. Cont. 


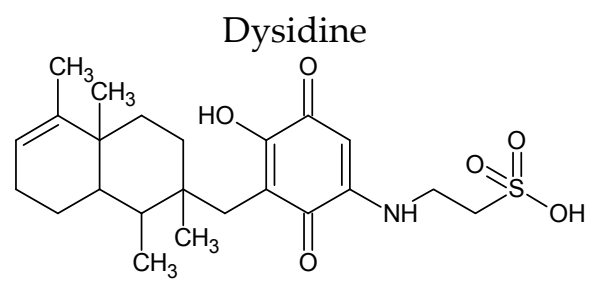

4-Methylenesteroid:

- Conicasterol<smiles>C=C1C(O)CCC2(C)C1CCC1=C3CCC4(C)C(=C3CCC12)CCC4C(C)CCC(C)C(C)C</smiles>

- Theonellasterol
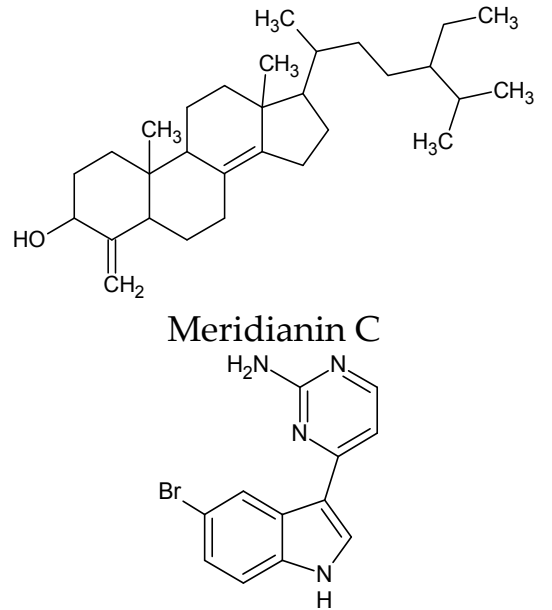

1,3-Dipalmitolein

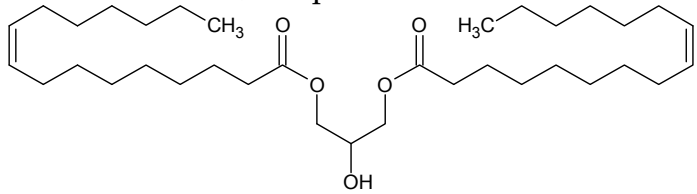

Cis-9-Octadecenoic Acid

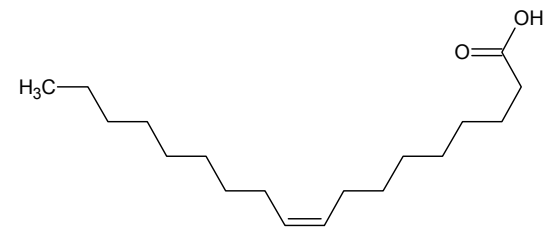

Fucoxanthin

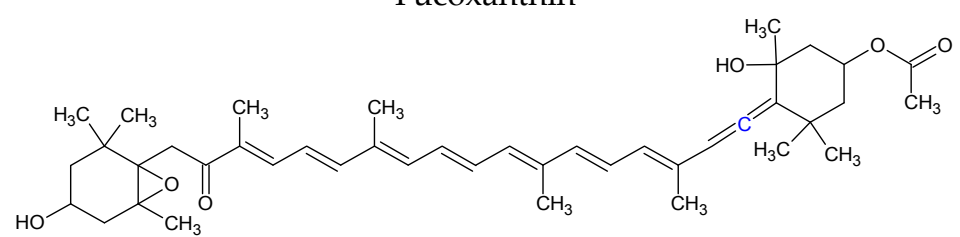

Fucoxanthinol

Figure 5. Cont. 

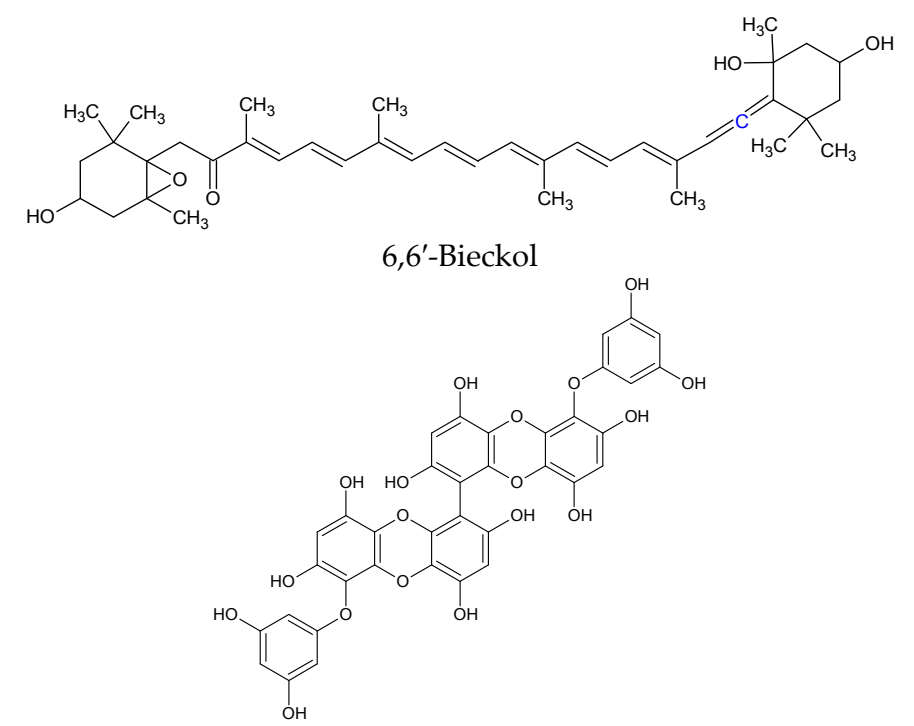

Ulva lactuca polysaccharides

Chemicalstructure of the repeating dimericunits of ulvan

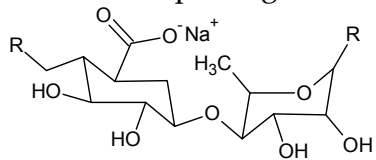

Fucosterol

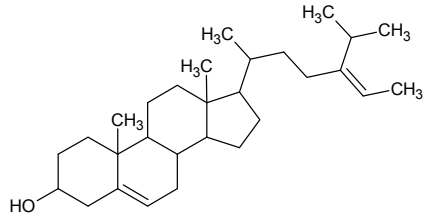

Astaxanthin<smiles>CC1=C(/C=C/C(C)=C/C=C/C(C)=C/C=C/C=C(C)/C=C/C=C(C)/C=C/C2=C(C)C(=O)C(O)CC2(C)C)C(C)(C)CC(O)C1=O</smiles><smiles>C=CC(C)(C)C12CC3C(=O)NC(Cc4ccccc4)C(=O)N3C1N(C(C)=O)c1ccccc12</smiles>

Cyclopenol<smiles>CN1C(=O)c2ccccc2NC(=O)C12OC2c1cccc(O)c1</smiles>

Figure 5. Cont. 
<smiles>C=CC(C)(C)c1[nH]c2c(CC=C(C)C)cc(CC=C(C)C)cc2c1CC1NC(=O)C(C)NC1=O</smiles><smiles>CCCCCCCc1c(O)cc(CC=C(C)C)c(O)c1C=O</smiles><smiles>O=c1[nH]c2ccccc2c(-c2cccc(O)c2)c1O</smiles><smiles>COc1oc(C/C=C(\C)CCC(OC)/C(C)=C/C(C)O)c(C)c(=O)c1C</smiles>
Yoshinone B<smiles>COc1oc(/C=C/C(C)(O)CCC(OC)/C(C)=C/C(C)O)c(C)c(=O)c1C</smiles>

Figure 5. Chemical structures of drugs reported on Table 2.

\section{Discussion}

Nowadays a single phenotype is determined by interconnected networks involving genome, transcriptome, proteome, metabolome and environment (Figure 3). This vision changes our approaches to disease from simplistic linear approaches to the person's capacity for health resilience and survival. Consequently, the term "multi-morbidity" viewed as simple sum of single diseases is misleading, reflecting an oversimplification. The so-called "multi-morbidities" are interconnected occurrences among a common interconnected network. In COPD, some co-occurring conditions may be linked to a common mechanism, such as systemic inflammation [3,98]; whether systemic inflammation spreads from airways tract into the circulation or systemic inflammatory state, involving many organs, spreads to the lung remains a question to be determined. Indeed, a study that integrated records from approximately 13 million patients from the Medicare database with disease-gene maps discovered a set of COPD co-morbidity candidate biomarkers that includes IL15, TNF and JUP (junction plakoglobin), and characterizes their association to aging and life-style conditions, such as smoking and physical activity [99]. Obesity and COPD share some mechanisms, such as inflammation, 
and there is interconnection between pathway activation/deactivation in adipose tissue and lung function modulation. It is well known that indicators of oxidative stress are augmented in COPD and reactive oxygen species (ROS) which may alter signaling pathways and antioxidant molecule function, are implicated in the pathogenesis of COPD, although their role in the development/progression of COPD is not fully proven, as recently reviewed in [100]. On the other hand, high levels of reactive oxygen species (ROS) are strictly linked to obesity and associated pathologies, notably insulin resistance and type 2 diabetes, as reviewed in [101]. It has been reported that ROS generation in contracting skeletal muscle is elevated when there is TNF- $\alpha$ overproduction in the lung and that this can induce muscle dysfunction $[102,103]$ as observed in COPD and obesity.

Since the introduction of the concept of inflammasomes, almost a decade ago, inflammasomes are considered the central player of both innate immune and inflammatory responses [104] and recently are considered implicated in different diseases including metabolic syndrome, obesity, respiratory, cardiovascular and neurodegenerative disorders [104-106]. Inflammasomes are complexes of multimeric proteins consisting of a sensor protein, the adapter protein ASC (apoptosis-associated speck-like protein containing a caspase recruitment domain), and caspase-1 [107,108]. The inflammasomes sensor proteins belong either to the NOD-like receptor (NLR) or to the AIM2-like receptor family. NLRP3 initiates pro-inflammatory signaling through recruitment and clustering of ASC, the zymogen protease, and caspase-1. Then caspase-1 is activated triggering a form of cell death called "pyroptosis" [107]. NLRP3 inflammasome is implicated in the progression of different non-communicable diseases. Surplus levels in nutrients associated with caloric overload as well as low-level of circulatory endotoxemia (LPS), as in the case of obesity, cause NLRP3 activation playing an important role in the perpetuation of insulin resistance and inflammation [109]. High expression of the NLRP3 genes is observed in the abdominal subcutaneous adipose tissue in obese adolescents [110] as well as in COPD patients [111]. In the neutrophils of COPD patients during acute exacerbation, an upregulation of NLRP3 mRNA expression in comparison with stable disease has been observed [112]. EPA + DHA can abolish the NLRP3 inflammasome activation, inhibiting the subsequent activation of caspase-1 [113].

In this review, different observations supporting our principal hypothesis of a link between obesity and COPD are reported and discussed. Although there is no a direct causal relation, the new biological data, presented here, as well as the clinical and epidemiological observations, reported in literature recently reviewed in [114] tend to suggest a link. Marine drugs acting on adipose tissue or on mechanism of inflammation may be helpful, not only in obesity control but also in subjects with high BMI and concomitant COPD. Whether these treatments affect COPD in a long-term positive perspective requires further investigations.

Acknowledgments: Images in Figures 1-4 were drawn using dreams-time free picture [115].

Author Contributions: All Authors contributed equally to the review.

Conflicts of Interest: The authors declare no conflict of interest.

\section{References}

1. Martinez, F.D. Early-Life Origins of Chronic Obstructive Pulmonary Disease. N. Engl. J. Med. 2016, 375, 871-878. [CrossRef] [PubMed]

2. Woodruff, P.G.; Agusti, A.; Roche, N.; Singh, D.; Martinez, F.J. Current concepts in targeting chronic obstructive pulmonary disease pharmacotherapy: Making progress towards personalised management. Lancet 2015, 385, 1789-1798. [CrossRef]

3. Vanfleteren, L.E.; Spruit, M.A.; Wouters, E.F.; Franssen, F.M. Management of chronic obstructive pulmonary disease beyond the lungs. Lancet Respir. Med. 2016, 4, 911-924. [CrossRef]

4. Perret, J.L.; Walters, E.H.; Abramson, M.J.; McDonald, C.F.; Dharmage, S.C. The independent and combined effects of lifetime smoke exposures and asthma as they relate to COPD. Expert Rev. Respir. Med. 2014, 8, 503-514. [CrossRef] [PubMed] 
5. Stoller, J.K.; Lacbawan, F.L.; Aboussouan, L.S. Alpha-1 Antitrypsin Deficiency. In GeneReviews®[Internet]; Pagon, R.A., Adam, M.P., Ardinger, H.H., Wallace, S.E., Amemiya, A., Bean, L.J.H., Bird, T.D., Ledbetter, N., Mefford, H.C., Smith, R.J.H., et al., Eds.; University of Washington: Seattle, WA, USA, 2006; pp. 1993-2017.

6. Halldén, S.; Sjögren, M.; Hedblad, B.; Engström, G.; Hamrefors, V.; Manjer, J.; Melander, O. Gene variance in the nicotinic receptor cluster (CHRNA5-CHRNA3-CHRNB4) predicts death from cardiopulmonary disease and cancer in smokers. J. Intern. Med. 2016, 279, 388-398. [CrossRef] [PubMed]

7. Freathy, R.M.; Kazeem, G.R.; Morris, R.W.; Johnson, P.C.; Paternoster, L.; Ebrahim, S.; Hattersley, A.T.; Hill, A.; Hingorani, A.D.; Holst, C.; et al. Genetic variation at CHRNA5-CHRNA3-CHRNB4 interacts with smoking status to influence body mass index. Int. J. Epidemiol. 2011, 40, 1617-1628. [CrossRef] [PubMed]

8. Varga, T.V.; Hallmans, G.; Hu, F.B.; Renström, F.; Franks, P.W. Smoking status, snus use, and variation at the CHRNA5-CHRNA3-CHRNB4 locus in relation to obesity: The GLACIER study. Am. J. Epidemiol. 2013, 178, 31-37. [CrossRef] [PubMed]

9. Chang, Y.; Glass, K.; Liu, Y.Y.; Silverman, E.K.; Crapo, J.D.; Tal-Singer, R.; Bowler, R.; Dy, J.; Cho, M.; Castaldi, P. COPD subtypes identified by network-based clustering of blood gene expression. Genomics 2016, 107, 51-58. [CrossRef] [PubMed]

10. Diaz, A.A.; Estépar, R.S.; Washko, G.R. Computed Tomographic Airway Morphology in Chronic Obstructive Pulmonary Disease. Remodeling or Innate Anatomy? Ann. Am. Thorac. Soc. 2016, 13, 4-9. [CrossRef] [PubMed]

11. López-Campos, J.L.; Tan, W.; Soriano, J.B. Global burden of COPD. Respirology 2016, 21, 14-23. [CrossRef] [PubMed]

12. Baffi, C.W.; Wood, L.; Winnica, D.; Strollo, P.J., Jr.; Gladwin, M.T.; Que, L.G.; Holguin, F. Metabolic Syndrome and the Lung. Chest 2016, 149, 1525-1534. [CrossRef] [PubMed]

13. Marquis, K.; Maltais, F.; Duguay, V.; Bezeau, A.M.; LeBlanc, P.; Jobin, J.; Poirier, P. The metabolic syndrome in patients with chronic obstructive pulmonary disease. J. Cardiopulm. Rehabil. 2005, 25, 226-232. [CrossRef] [PubMed]

14. Cebron Lipovec, N.; Beijers, R.J.; van den Borst, B.; Doehner, W.; Lainscak, M.; Schols, A.M. The Prevalence of Metabolic Syndrome in Chronic Obstructive Pulmonary Disease: A Systematic Review. COPD 2016, 3 , 399-406. [CrossRef] [PubMed]

15. Kisiliaou, A.; Lococo, F.; Prinzi, G.; Fini, M.; Bonassi, S.; Russo, P. Pharmacological Management of Chronic Obstructive Lung Disease (COPD) in the Post-Genome Era. Evidence from a Real-World Perspective. Curr. Med. Chem. 2017. accepted.

16. Global Initiative for Chronic Obstructive Lung Disease. Available online: http://www.goldcopd.it/ materiale/2015/GOLD_Pocket_2015.pdf (accessed on 24 October 2016).

17. Carcache de Blanco, E. Review of Drugs of Natural Origin. In A Treatise of Pharmacognosy, 7th Revised ed.; Samuelsson, G., Bohlin, L., Eds.; Apotekarsocieteten, Swedish Pharmaceutical Society: Stockholm, Sweden, 2015; pp. 1-807.

18. Li, J.W.; Vederas, J.C. Drug discovery and natural products: End of an era or an endless frontier? Science 2009, 325, 161-165. [CrossRef] [PubMed]

19. Backes, J.; Anzalone, D.; Hilleman, D.; Catini, J. The clinical relevance of omega-3 fatty acids in the management of hypertriglyceridemia. Lipids Health Dis. 2016, 15, 118-130. [CrossRef] [PubMed]

20. Baker, E.J.; Miles, E.A.; Burdge, G.C.; Yaqoob, P.; Calder, P.C. Metabolism and functional effects of plant-derived omega-3 fatty acids in humans. Prog. Lipid Res. 2016, 64, 30-56. [CrossRef] [PubMed]

21. Chiesa, G.; Busnelli, M.; Manzini, S.; Parolini, C. Nutraceuticals and Bioactive Components from Fish for Dyslipidemia and Cardiovascular Risk Reduction. Mar. Drugs. 2016, 14, 113. [CrossRef] [PubMed]

22. Todorčević, M.; Hodson, L. The Effect of Marine Derived n-3 Fatty Acids on Adipose Tissue Metabolism and Function. J. Clin. Med. 2015, 5, E3. [CrossRef] [PubMed]

23. Martínez-Fernández, L.; Laiglesia, L.M.; Huerta, A.E.; Martínez, J.A.; Moreno-Aliaga, M.J. Omega-3 fatty acids and adipose tissue function in obesity and metabolic syndrome. Prostaglandins Other Lipid Mediat. 2015, 121, 24-41. [CrossRef] [PubMed]

24. Celli, B.R.; Cote, C.G.; Marin, J.M.; Casanova, C.; Montes de Oca, M.; Mendez, R.A.; Pinto Plata, V.; Cabral, H.J. The body-mass index, airflow obstruction, dyspnea, and exercise capacity index in chronic obstructive pulmonary disease. N. Engl. J. Med. 2004, 350, 1005-1012. [CrossRef] [PubMed] 
25. Garcia-Rio, F.; Soriano, J.B.; Miravitlles, M.; Muñoz, L.; Duran-Tauleria, E.; Sánchez, G.; Sobradillo, V.; Ancochea, J. Impact of obesity on the clinical profile of a population-based sample with chronic obstructive pulmonary disease. PLoS ONE 2014, 9, e105220. [CrossRef] [PubMed]

26. O'Donnell, D.E.; Ciavaglia, C.E.; Neder, J.A. When obesity and chronic obstructive pulmonary disease collide. Physiological and clinical consequences. Ann. Am. Thorac. Soc. 2014, 11, 635-644. [CrossRef] [PubMed]

27. Joppa, P.; Tkacova, R.; Franssen, F.M.; Hanson, C.; Rennard, S.I.; Silverman, E.K.; McDonald, M.L.; Calverley, P.M.; Tal-Singer, R.; Spruit, M.A.; et al. Sarcopenic Obesity Functional Outcomes and Systemic Inflammation in Patients With Chronic Obstructive Pulmonary Disease. J. Am. Med. Dir. Assoc. 2016, 17, 712-718. [CrossRef] [PubMed]

28. Finucane, M.M.; Stevens, G.A.; Cowan, M.J.; Danaei, G.; Lin, J.K.; Paciorek, C.J.; Singh, G.M.; Gutierrez, H.R.; Lu, Y.; Bahalim, A.N.; et al. National, regional, and global trends in bodymass index since 1980: Systematic analysis of health examination surveys and epidemiological studies with 960 country-years and 9.1 million participants. Lancet 2011, 377, 557-567. [CrossRef]

29. Lambert, A.A.; Putcha, N.; Drummond, M.B.; Boriek, A.M.; Hanania, N.A.; Kim, V.; Kinney, G.L.; McDonald, M.N.; Brigham, E.P.; Wise, R.A.; et al. Obesity is Associated with Increased Morbidity in Moderate to Severe COPD. Chest 2017, 151, 68-77. [CrossRef] [PubMed]

30. Chittal, P.; Babu, A.S.; Lavie, C.J. Obesity paradox: Does fat alter outcomes in chronic obstructive pulmonary disease? COPD 2015, 12, 14-18. [CrossRef] [PubMed]

31. Çolak, Y.; Afzal, S.; Lange, P.; Nordestgaard, B.G. High body mass index and risk of exacerbations and pneumonias in individuals with chronic obstructive pulmonary disease: Observational and genetic risk estimates from the Copenhagen General Population Study. Int. J. Epidemiol. 2016, 45, 1551-1559. [CrossRef] [PubMed]

32. Bianco, A.; Nigro, E.; Monaco, M.L.; Matera, M.G.; Scudiero, O.; Mazzarella, G.; Daniele, A. The burden of obesity in asthma and COPD: Role of adiponectin. Pulm. Pharmacol. Ther. 2017, 43, 20-25. [CrossRef] [PubMed]

33. Suzuki, M.; Makita, H.; Östling, J.; Thomsen, L.H.; Konno, S.; Nagai, K.; Shimizu, K.; Pedersen, J.H.; Ashraf, H.; Bruijnzeel, P.L.; et al. Lower leptin/adiponectin ratio and risk of rapid lung function decline in chronic obstructive pulmonary disease. Ann. Am. Thorac. Soc. 2014, 11, 1511-1519. [CrossRef] [PubMed]

34. Oh, Y.M.; Jeong, B.H.; Woo, S.Y.; Kim, S.Y.; Kim, H.; Lee, J.H.; Lim, S.Y.; Rhee, C.K.; Yoo, K.H.; Lee, J.H.; et al. Association of plasma adipokines with chronic obstructive pulmonary disease severity and progression. Ann. Am. Thorac. Soc. 2015, 12, 1005-1012. [CrossRef] [PubMed]

35. Pajvani, U.B.; Du, X.; Combs, T.P.; Berg, A.H.; Rajala, M.W.; Schulthess, T.; Engel, J.; Brownlee, M.; Scherer, P.E. Structure-function studies of the adipocyte-secreted hormone Acrp30/adiponectin. Implications for metabolic regulation and bioactivity. J. Biol. Chem. 2003, 278, 9073-9085. [CrossRef] [PubMed]

36. Tsao, T.S.; Murrey, H.E.; Hug, C.; Lee, D.H.; Lodish, H.F. Oligomerization state-dependent activation of NF-kB signaling pathway by adipocyte complement-related protein of $30 \mathrm{kDa}$ (Acrp30). J. Biol. Chem. 2002, 277, 29359-29362. [CrossRef] [PubMed]

37. Friedman, J.M.; Halaas, J.L. Leptin and the regulation of body weight in mammals. Nature 1998, 395, 763-770. [CrossRef] [PubMed]

38. Flegal, K.M.; Carroll, M.D.; Kit, B.K.; Ogden, C.L. Prevalence of obesity and trends in the distribution of body mass index among US adults, 1999-2010. JAMA 2012, 307, 491-497. [CrossRef] [PubMed]

39. Stephens, J.M. The Fat Controller: Adipocyte Development. PLoS Biol. 2012, 10, 11-13. [CrossRef] [PubMed]

40. Berrigan, D.; Troiano, R.P.; Graubard, B.I. BMI and mortality: The limits of epidemiological evidence. Lancet 2016, 388, 734-736. [CrossRef]

41. WHO. Obesity and Overweight. Available online: http://www.who.int/mediacentre/factsheets/fs311/en/ (accessed on 24 October 2016).

42. Cawley, J.; Meyerhoefer, C.; Biener, A.; Hammer, M.; Wintfeld, N. Savings in Medical Expenditures Associated with Reductions in Body Mass Index Among US Adults with Obesity, by Diabetes Status. Pharmacoeconomics 2015, 33, 707-722. [CrossRef] [PubMed]

43. Assfalg, M.; Bertini, I.; Colangiuli, D.; Luchinat, C.; Schäfer, H.; Schütz, B.; Spraul, M. Evidence of different metabolic phenotypes in humans. Proc. Natl. Acad. Sci. USA 2008, 105, 1420-1424. [CrossRef] [PubMed]

44. Ghini, V.; Saccenti, E.; Tenori, L.; Assfalg, M.; Luchinat, C. Allostasis and Resilience of the Human Individual Metabolic Phenotype. J. Proteome Res. 2015, 14, 2951-2962. [CrossRef] [PubMed] 
45. Johnson, A.R.; Makowski, L. Nutrition and metabolic correlates of obesity and inflammation: Clinical considerations. J. Nutr. 2015, 145, 1131S-1136S. [CrossRef] [PubMed]

46. Koen, N.; Du Preez, I.; Loots, D.T. Metabolomics and Personalized Medicine. Adv. Protein Chem. Struct. Biol. 2016, 102, 53-78. [PubMed]

47. Kim, G.W.; Lin, J.E.; Blomain, E.S.; Waldman, S. New advances in models and strategies for developing anti-obesity drugs. Expert Opin. Drug Discov. 2013, 8, 655-671. [CrossRef] [PubMed]

48. Saunders, K.H.; Shukla, A.P.; Igel, L.I.; Kumar, R.B.; Aronne, L. Pharmacotherapy for Obesity. Endocrinol. Metab. Clin. N. Am. 2016, 45, 521-538. [CrossRef] [PubMed]

49. FDA. Press Announcements. Available online: http://www.fda.gov/NewsEvents/Newsroom/ PressAnnouncements/ucm427913.htm (accessed on 24 October 2016).

50. EMA. News and Event. Available online: http://www.ema.europa.eu/ema/index.jsp?curl=pages/news_and_ events/news/2015/01/news_detail_002255.jsp\&mid=WC0b01ac058004d5c1 (accessed on 24 October 2016).

51. Jia, W.; Gao, W.Y.; Yan, Y.Q.; Wang, J.; Xu, Z.H.; Zheng, W.J.; Xiao, P.G. The rediscovery of ancient Chinese herbal formulas. Phytother. Res. 2004, 18, 681-686. [CrossRef] [PubMed]

52. Castro, M.; Preto, M.; Vasconcelos, V.; Urbatzka, R. Obesity: The Metabolic Disease, Advances on Drug Discovery and Natural Product Research. Curr. Top. Med. Chem. 2016, 16, 2577-2604. [CrossRef] [PubMed]

53. Monk, B.J.; Lorusso, D.; Italiano, A.; Kaye, S.B.; Aracil, M.; Tanović, A.; D’Incalci, M. Trabectedin as a chemotherapy option for patients with BRCA deficiency. Cancer Treat. Rev. 2016, 50, 175-182. [CrossRef] [PubMed]

54. Long, S.; Sousa, E.; Kijjoa, A.; Pinto, M.M. Marine Natural Products as Models to Circumvent Multidrug Resistance. Molecules 2016, 21, 892. [CrossRef] [PubMed]

55. Russo, P.; Cesario, A. New anticancer drugs from marine cyanobacteria. Curr. Drug Targets 2012, 13, 1048-1053. [CrossRef] [PubMed]

56. Russo, P.; Del Bufalo, A.; Fini, M. Deep sea as a source of novel-anticancer drugs: Update on discovery and preclinical/clinical evaluation in a systems medicine perspective. EXCLI J. 2015, 14, 228-236. [PubMed]

57. Russo, P.; Kisialiou, A.; Lamonaca, P.; Moroni, R.; Prinzi, G.; Fini, M. New Drugs from Marine Organisms in Alzheimer's Disease. Mar. Drugs 2015, 14, 5. [CrossRef] [PubMed]

58. Nastrucci, C.; Cesario, A.; Russo, P. New anticancer drugs from marine cyanobacteria. Anticancer drug discovery from the marine environment. Recent Pat. Anticancer Drug Discov. 2012, 7, 218-232. [CrossRef] [PubMed]

59. Calder, P.C. Marine omega-3 fatty acids and inflammatory processes: Effects, mechanisms and clinical relevance. Biochim. Biophys. Acta 2015, 1851, 469-484. [CrossRef] [PubMed]

60. Label. FDA. Available online: http://www.accessdata.fda.gov/drugsatfda_docs/label/2014/021654s041lbl.pdf (accessed on 24 October 2016).

61. Gold, D.R.; Litonjua, A.A.; Carey, V.J.; Manson, J.E.; Buring, J.E.; Lee, I.M.; Gordon, D.; Walter, J.; Friedenberg, G.; Hankinson, J.L.; et al. Lung VITAL: Rationale, design, and baseline characteristics of an ancillary study evaluating the effects of vitamin D and/or marine omega-3 fatty acid supplements on acute exacerbations of chronic respiratory disease, asthma control, pneumonia and lung function in adults. Contemp. Clin Trials 2016, 47, 185-195. [PubMed]

62. Maki, K.C.; Reeves, M.S.; Farmer, M.; Griinari, M.; Berge, K.; Vik, H.; Hubacher, R.; Rains, T.M. Krill oil supplementation increases plasma concentrations of eicosapentaenoic and docosahexaenoic acids in overweight and obese men and women. Nutr. Res. 2009, 9, 609-615. [CrossRef] [PubMed]

63. Banni, S.; Carta, G.; Murru, E.; Cordeddu, L.; Giordano, E.; Sirigu, A.R.; Berge, K.; Vik, H.; Maki, K.C.; Di Marzo, V.; et al. Krill oil significantly decreases 2-arachidonoylglycerol plasma levels in obese subjects. Nutr. Metab. 2011, 8, 7. [CrossRef] [PubMed]

64. Höper, A.C.; Salma, W.; Khalid, A.M.; Hafstad, A.D.; Sollie, S.J.; Raa, J.; Larsen, T.S.; Aasum, E. Oil from the marine zooplankton Calanus finmarchicus improves the cardiometabolic phenotype of diet-induced obese mice. Br. J. Nutr. 2013, 110, 2186-2193. [CrossRef] [PubMed]

65. Höper, A.C.; Salma, W.; Sollie, S.J.; Hafstad, A.D.; Lund, J.; Khalid, A.M.; Raa, J.; Aasum, E.; Larsen, T.S. Wax esters from the marine copepod Calanus finmarchicus reduce diet-induced obesity and obesity-related metabolic disorders in mice. J. Nutr. 2014, 144, 164-169. [CrossRef] [PubMed] 
66. Abdjul, D.B.; Kanno, S.; Yamazaki, H.; Ukai, K.; Namikoshi, M.A. Dimeric urea of the bisabolene sesquiterpene from the Okinawan marine sponge Axinyssa sp. inhibits protein tyrosine phosphatase 1B activity in Huh-7 human hepatoma cells. Bioorg. Med. Chem. Lett. 2016, 26, 315-317. [CrossRef] [PubMed]

67. Yamazaki, H.; Takahashi, O.; Kanno, S.; Nakazawa, T.; Takahashi, S.; Ukai, K.; Sumilat, D.A.; Ishikawa, M.; Namikoshi, M. Absolute structures and bioactivities of euryspongins and eurydiene obtained from the marine sponge Euryspongia sp. collected at Iriomote Island. Bioorg. Med. Chem. 2015, 23, 797-802. [CrossRef] [PubMed]

68. Liang, L.F.; Wang, T.; Cai, Y.S.; He, W.F.; Sun, P.; Li, Y.F.; Huang, Q.; Taglialatela-Scafati, O.; Wang, H.Y.; Guo, Y.W. Brominated polyunsaturated lipids from the Chinese sponge Xestospongia testudinaria as a new class of pancreatic lipase inhibitors. Eur. J. Med. Chem. 2014, 79, 290-297. [CrossRef] [PubMed]

69. He, W.F.; Xue, D.Q.; Yao, L.G.; Li, J.; Liu, H.L.; Guo, Y.W. A new bioactive steroidal ketone from the South China Sea sponge Xestospongia testudinaria. J. Asian Nat. Prod. Res. 2016, 18, 195-199. [CrossRef] [PubMed]

70. Salim, A.A.; Rae, J.; Fontaine, F.; Conte, M.M.; Khalil, Z.; Martin, S.; Parton, R.G.; Capon, R.J. Heterofibrins: Inhibitors of lipid droplet formation from a deep-water southern Australian marine sponge, Spongia (Heterofibria) sp. Org. Biomol. Chem. 2010, 8, 3188-3194. [CrossRef] [PubMed]

71. Sun, T.; Wang, Q.; Yu, Z.; Zhang, Y.; Guo, Y.; Chen, K.; Shen, X.; Jiang, H. Hyrtiosal, a PTP1B inhibitor from the marine sponge Hyrtios erectus, shows extensive cellular effects on PI3K/AKT activation, glucose transport, and TGFbeta/Smad2 signaling. ChemBioChem 2007, 8, 187-193. [CrossRef] [PubMed]

72. Byun, M.R.; Lee, C.H.; Hwang, J.H.; Kim, A.R.; Moon, S.A.; Sung, M.K.; Roh, J.R.; Hwang, E.S.; Hong, J.H. Phorbaketal A inhibits adipogenic differentiation through the suppression of PPAR $\gamma$-mediated gene transcription by TAZ. Eur. J. Pharmacol. 2013, 718, 181-187. [CrossRef] [PubMed]

73. Seo, Y.J.; Lee, K.T.; Rho, J.R.; Choi, J.H. Phorbaketal A, Isolated from the Marine Sponge Phorbas sp., Exerts Its Anti-Inflammatory Effects via NF-kB Inhibition and Heme Oxygenase-1 Activation in Lipopolysaccharide-Stimulated Macrophages. Mar. Drugs 2015, 13, 7005-7019. [CrossRef] [PubMed]

74. Zhang, Y.; Li, Y.; Guo, Y.; Jiang, H.; Shen, X. A sesquiterpenequinone, dysidine, from the sponge Hyrtios erectus, activates the insulin pathway through inhibition of PTPases. Acta Pharmacol. Sin. 2009, 30, 333-345. [CrossRef] [PubMed]

75. Sepe, V.; D’Amore, C.; Ummarino, R.; Renga, B.; D’Auria, M.V.; Novellino, E.; Sinisi, A.; Taglialatela-Scafati, O.; Nakao, Y.; Limongelli, V.; et al. Insights on pregnane-X-receptor modulation. Natural and semisynthetic steroids from Theonella marine sponges. Eur. J. Med. Chem. 2014, 73, 126-134. [CrossRef] [PubMed]

76. Park, Y.; Lee, T.; Choi, J.; Sukbong, V.; Lee, J.; Park, J.; Jang, B. Inhibition of adipogenesis and leptin production in 3T3-L1 adipocytes by a derivative of meridianin C. Biochem. Biophys. Res. Commun. 2014, 452, 1078-1083. [CrossRef] [PubMed]

77. Nguyen, T.H.; Kim, S.M. $\alpha$-Glucosidase inhibitory activities of fatty acids purified from the internal organ of sea cucumber Stichopus japonicas. J. Food Sci. 2015, 80, H841-H847. [CrossRef] [PubMed]

78. Gammone, M.A.; D'Orazio, N. Anti-obesity activity of the marine carotenoid fucoxanthin. Mar. Drugs 2015, 13, 2196-2214. [CrossRef] [PubMed]

79. Miyashita, K.; Nishikawa, S.; Beppu, F.; Tsukui, T.; Abe, M.; Hosokawa, M. The allenic carotenoid fucoxanthin, a novel marine nutraceutical from brown seaweeds. J. Sci. Food Agric. 2011, 91, 1166-1174. [CrossRef] [PubMed]

80. Peng, J.; Yuan, J.P.; Wu, C.F.; Wang, J.H. Fucoxanthin, a marine carotenoid present in brown seaweeds and diatoms: Metabolism and bioactivities relevant to human health. Mar. Drugs 2011, 9, 1806-1828. [CrossRef] [PubMed]

81. Hosokawa, M.; Miyashita, T.; Nishikawa, S.; Emi, S.; Tsukui, T.; Beppu, F.; Okada, T.; Miyashita, K. Fucoxanthin regulates adipocytokine mRNA expression in white adipose tissue of diabetic/obese KK-Ay mice. Arch. Biochem. Biophys. 2010, 504, 17-25. [CrossRef] [PubMed]

82. Beppu, F.; Hosokawa, M.; Yim, M.J.; Shinoda, T.; Miyashita, K. Down-regulation of hepatic stearoyl-CoA desaturase-1 expression by fucoxanthin via leptin signaling in diabetic/obese KK-A(y) mice. Lipids 2013, 48, 449-455. [CrossRef] [PubMed]

83. Matsumoto, M.; Hosokawa, M.; Matsukawa, N.; Hagio, M.; Shinoki, A.; Nishimukai, M.; Miyashita, K.; Yajima, T.; Hara, H. Suppressive effects of the marine carotenoids.; fucoxanthin and fucoxanthinol on triglyceride absorption in lymph duct-cannulated rats. Eur. J. Nutr. 2010, 49, 243-249. [CrossRef] [PubMed] 
84. Maeda, H.; Hosokawa, M.; Sashima, T.; Miyashita, K. Dietary combination of fucoxanthin and fish oil attenuates the weight gain of white adipose tissue and decreases blood glucose in obese/diabetic KK-Ay mice. J. Agric. Food Chem. 2007, 55, 7701-7706. [CrossRef] [PubMed]

85. Maeda, H.; Kanno, S.; Kodate, M.; Hosokawa, M.; Miyashita, K. Fucoxanthinol, Metabolite of Fucoxanthin, Improves Obesity-Induced Inflammation in Adipocyte Cells. Mar. Drugs 2015, 13, 4799-4813. [CrossRef] [PubMed]

86. Jung, H.A.; Jung, H.J.; Jeong, H.Y.; Kwon, H.J.; Kim, M.S.; Choi, J.S. Anti-adipogenic activity of the edible brown alga Ecklonia stolonifera and its constituent fucosterol in 3T3-L1 adipocytes. Arch. Pharm. Res. 2014, 37, 713-720. [CrossRef] [PubMed]

87. Kwon, T.H.; Wu, Y.X.; Kim, J.S.; Woo, J.H.; Park, K.T.; Kwon, O.; Seo, H.J.; Kim, T.; Park, N.H. 6,6'-Bieckol inhibits adipocyte differentiation through downregulation of adipogenesis and lipogenesis in 3T3-L1 cells. J. Sci. Food Agric. 2015, 95, 1830-1837. [CrossRef] [PubMed]

88. BelHadj, S.; Hentati, O.; Elfeki, A.; Hamden, K. Inhibitory activities of Ulva lactuca polysaccharides on digestive enzymes related to diabetes and obesity. Arch. Physiol. Biochem. 2013, 119, 81-87. [CrossRef] [PubMed]

89. Kim, J.H.; Kim, S.M.; Cha, K.H. Evaluation of the anti-obesity effect of the microalga Phaeodactylum tricornutum. Appl. Biol. Chem. 2016, 59, 283. [CrossRef]

90. Arunkumar, E.; Bhuvaneswari, S.; Anuradha, C.V. An intervention study in obese mice with astaxanthin, a marine carotenoid-effects on insulin signaling and pro-inflammatory cytokines. Food Funct. 2012, 3, 120-126. [CrossRef] [PubMed]

91. Franceschelli, S.; Pesce, M.; Ferrone, A.; De Lutiis, M.A.; Patruno, A.; Grilli, A.; Felaco, M.; Speranza, L. Astaxanthin treatment confers protection against oxidative stress in U937 cells stimulated with lipopolysaccharide reducing $\mathrm{O}_{2}^{-}$production. PLoS ONE 2014, 9, e88359. [CrossRef] [PubMed]

92. Ikeuchi, M.; Koyama, T.; Takahashi, J.; Yazawa, K. Effects of astaxanthin in obese mice fed a high-fat diet. Biosci. Biotechnol. Biochem. 2007, 71, 893-899. [CrossRef] [PubMed]

93. Sohn, J.H.; Lee, Y.R.; Lee, D.S.; Kim, Y.C.; Oh, H. PTP1B inhibitory secondary metabolites from marine-derived fungal strains Penicillium spp. and Eurotium sp. J. Microbiol. Biotechnol. 2013, 23, 1206-1211. [CrossRef] [PubMed]

94. Koyama, T.; Kawazoe, Y.; Iwasaki, A.; Ohno, O.; Suenaga, K.; Uemura, D. Anti-obesity activities of the yoshinone A and therelated marine $\gamma$-pyrone compounds. J. Antibiot. 2016, 69, 348-351. [CrossRef] [PubMed]

95. Thiebaut, P.A.; Besnier, M.; Gomez, E.; Richard, V. Role of protein tyrosine phosphatase 1B in cardiovascular diseases. J. Mol. Cell. Cardiol. 2016, 101, 50-57. [CrossRef] [PubMed]

96. Breyer, M.K.; Rutten, E.P.; Vernooy, J.H.; Spruit, M.A.; Dentener, M.A.; van der Kallen, C.; van Greevenbroek, M.M.; Wouters, E.F. Gender differences in the adipose secretome system in chronic obstructive pulmonary disease (COPD): A pivotal role of leptin. Respir. Med. 2011, 105, 1046-1053. [CrossRef] [PubMed]

97. Breyer, M.K.; Rutten, E.P.; Locantore, N.W.; Watkins, M.L.; Miller, B.E.; Wouters, E.F.; ECLIPSE Investigators (Evaluation of COPD Longitudinally to Identify Predictive Surrogate Endpoints). Dysregulated adipokine metabolism in chronic obstructive pulmonary disease. Eur. J. Clin. Investig. 2012, 42, 983-991. [CrossRef] [PubMed]

98. Lococo, F.; Cesario, A.; Del Bufalo, A.; Ciarrocchi, A.; Prinzi, G.; Mina, M.; Bonassi, S.; Russo, P. Novel therapeutic strategy in the management of COPD: A systems medicine approach. Curr. Med. Chem. 2015, 22, 3655-3675. [CrossRef] [PubMed]

99. Gomez-Cabrero, D.; Menche, J.; Vargas, C.; Cano, I.; Maier, D.; Barabási, A.L.; Tegnér, J.; Roca, J.; Synergy-COPD Consortia. From comorbidities of chronic obstructive pulmonary disease to identification of shared molecular mechanisms by data integration. BMC Bioinform. 2016, 17 (Suppl. 15), 441. [CrossRef] [PubMed]

100. McGuinness, A.J.; Sapey, E. Oxidative Stress in COPD. Markers and Potential Mechanisms. J. Clin. Med. 2017, 15. [CrossRef] [PubMed]

101. McMurray, F.; Patten, D.A.; Harper, M.E. Reactive Oxygen Species and Oxidative Stress in Obesity-Recent Findings and Empirical Approaches. Obesity 2016, 24, 2301-2310. [CrossRef] [PubMed]

102. Zuo, L.; Hallman, A.H.; Roberts, W.J.; Wagner, P.D.; Hogan, M.C. Superoxide release from contracting skeletal muscle in pulmonary TNF- $\alpha$ overexpression mice. Am. J. Physiol. Regul. Integr. Comp. Physiol. 2014, 306, R75-R81. [CrossRef] [PubMed] 
103. Zuo, L.; Shiah, A.; Roberts, W.J.; Chien, M.T.; Wagner, P.D.; Hogan, M.C. Low $\mathrm{Po}_{2}$ conditions induce reactive oxygen species formation during contractions in single skeletal muscle fibers. Am. J. Physiol. Regul. Integr. Comp. Physiol. 2013, 304, R1009-R1016. [CrossRef] [PubMed]

104. Guo, H.; Callaway, J.B.; Ting, J.P. Inflammasomes: Mechanism of action, role in disease and therapeutics. Nat. Med. 2015, 21, 677-687. [CrossRef] [PubMed]

105. Brusselle, G.G.; Provoost, S.; Bracke, K.R.; Kuchmiy, A.; Lamkanfi, M. Inflammasomes in respiratory disease: From bench to bedside. Chest 2014, 145, 1121-1133. [CrossRef] [PubMed]

106. Robbins, G.R.; Wen, H.; Ting, J.P. Inflammasomes and metabolic disorders: Old genes in modern diseases. Mol. Cell 2014, 54, 297-308. [CrossRef] [PubMed]

107. Stehlik, C.; Lee, S.H.; Dorfleutner, A.; Stassinopoulos, A.; Sagara, J.; Reed, J.C. Apoptosis-associated speck-like protein containing a caspase recruitment domain is a regulator of procaspase-1 activation. J. Immunol. 2003, 171, 6154-6163. [CrossRef] [PubMed]

108. Coll, R.C.; O'Neill, L.; Schroder, K. Questions and controversies in innate immune research: What is the physiological role of NLRP3? Cell Death Discov. 2016, 2, 16019. [CrossRef] [PubMed]

109. Traba, J.; Sack, M.N. The role of caloric load and mitochondrial homeostasis in the regulation of the NLRP3 inflammasome. Cell. Mol. Life Sci. 2016. [CrossRef] [PubMed]

110. Kursawe, R.; Dixit, V.D.; Scherer, P.E.; Santoro, N.; Narayan, D.; Gordillo, R.; Giannini, C.; Lopez, X.; Pierpont, B.; Nouws, J.; et al. A Role of the Inflammasome in the Low Storage Capacity of the Abdominal Subcutaneous Adipose Tissue in Obese Adolescents. Diabetes 2016, 65, 610-618. [CrossRef] [PubMed]

111. Wright, T.K.; Gibson, P.G.; Simpson, J.L.; McDonald, V.M.; Wood, L.G.; Baines, K.J. Neutrophil extracellular traps are associated with inflammation in chronic airway disease. Respirology 2016, 21, 467-475. [CrossRef] [PubMed]

112. Pouwels, S.D.; van Geffen, W.H.; Jonker, M.R.; Kerstjens, H.A.; Nawijn, M.C.; Heijink, I.H. Increased neutrophil expression of pattern recognition receptors during COPD exacerbations. Respirology 2017, 22, 401-404. [CrossRef] [PubMed]

113. Yan, Y.; Jiang, W.; Spinetti, T.; Tardivel, A.; Castillo, R.; Bourquin, C.; Guarda, G.; Tian, Z.; Tschopp, J.; Zhou, R. Omega-3 fatty acids prevent inflammation and metabolic disorder through inhibition of NLRP3 inflammasome activation. Immunity 2013, 38, 1154-1163. [CrossRef] [PubMed]

114. Hanson, C.; LeVan, T. Obesity and chronic obstructive pulmonary disease: Recent knowledge and future directions. Curr. Opin. Pulm. Med. 2017, 23, 149-153. [CrossRef] [PubMed]

115. Dreamstime. Available online: https://www.dreamstime.com/photos-images/safe.html (accessed on 10 February 2017).

(C) 2017 by the authors. Licensee MDPI, Basel, Switzerland. This article is an open access article distributed under the terms and conditions of the Creative Commons Attribution (CC BY) license (http:/ / creativecommons.org/licenses/by/4.0/). 